\title{
Female Interventions in Politics in the libera res publica: Structures and Practices
}

\author{
Lewis Webb
}

\begin{abstract}
This chapter charts the structures and practices of female interventions in politics in the libera res publica (509-27 BCE). Previous scholarship has emphasized the efflorescence of female political activity in the first century вСE. Yet Greek and Roman authors retrojected such activity into their histories of early Rome: mytho-historical paradigms are the intercession of the Sabine women and of Veturia with Coriolanus. Furthermore, female benefactions saved Rome from financial and military crises in the fourth and third centuries BCE. For such interventions, women received enduring privileges and status symbols. Moving beyond previous scholarship, I argue that the interventions of senatorial women like Servilia, Iulia, Terentia, Hortensia, and Octavia were not novel, but a manifestation of a long tradition of women seizing political initiative. This chapter outlines and evaluates some of the structures of female interventionsthe ordo matronarum, matronal meetings, and religious roles - and their practicesintercession, benefactions, and participation in family consilia. Through numerous formal and informal initiatives, inside and outside of the domus, women proactively engaged in the res publica.
\end{abstract}

\section{Keywords}

Roman women - politics - res publica - ordo matronarum - matronal meetings - religious roles - intercession - benefactions - family consilia 
So Terentia-who was generally neither of a mild nor undaring nature, but an ambitious woman, and, as Cicero says himself, more likely to participate in his political affairs than to share with him her domestic affairs - told him this [interpretation of the omen] and incited him against the men. ${ }^{1}$

I see you [Terentia] are taking on every burden; I fear you may not endure, but I see everything is dependent upon you. ${ }^{2}$

When he [Brutus] takes his mother's [Servilia] counsel, or even her prayers, why should I interfere? ${ }^{3}$

And when I began to speak on what should have been done ... your friend [Servilia] exclaimed: “Truly, I've never heard anyone say that!" I restrained myself. ... (Moreover, Servilia promised to arrange that the grain commission be removed from the senatorial decree. $)^{4}$

1 Plut. Cic. 20.3 (Cicero and Terentia, during his consulship in 63): $\dot{\eta} \delta \varepsilon \dot{~ T \varepsilon p \varepsilon v \tau i ́ \alpha — \chi \alpha i ~ \gamma \alpha ̀ ~}$

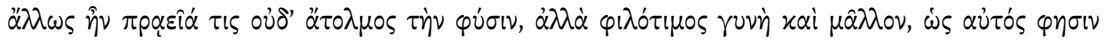

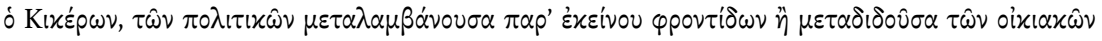

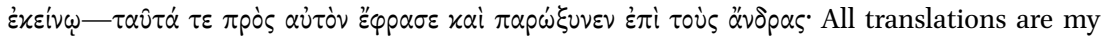
own. Latin from PHI Latin Texts and Greek from the TLG. Many thanks to Lovisa Brännstedt, Harriet Flower, Tom Hillard, Karl-Joachim Hölkeskamp, Brad Jordan, and Irene Selsvold for feedback on earlier iterations of this chapter. I am grateful to Lea Beness, Harriet Flower, Tom Hillard, Josiah Osgood, Francesca Rohr Vio, Cristina Rosillo-López, Catherine Steel, and Kathryn Welch for conversations on Roman women. All errors remain my own. All dates are вСЕ. All magistracies: Broughton 1951; 1952. Research funded by the Swedish Research Council (2019-06370).

2 Cic. Fam. 14.2.3 (Cicero to Terentia, during his exile, October 58 ): omnis labores te excipere video; timeo ut sustineas, sed video in te esse omnia.

3 Cic. Att. 15.10 (Cicero to Atticus, June 44): matris consilio cum utatur vel etiam precibus, quid me interponam? Cf. Cic. Ad Brut. 26.1 on this relationship between Servilia and Brutus.

4 Cic. Att. 15.11.2 (Cicero to Atticus, Servilia's consilium at Antium, June 44): cumque ingressus essem dicere quid oportuisset ... exclamat tua familiaris "hoc vero neminem umquam audivi!" ego $\langle$ me $\rangle$ repressi. ... (etenim Servilia pollicebatur se curaturam ut illa frumenti curatio de senatus consulto tolleretur). Cf. Asc. ${ }_{19} \mathrm{C}$ on the maternal authority (materna auctoritas) Servilia held over her half-brother Cato. 
Were Roman women excluded from politics in the libera res publica (50927)? A cursory glance at the ancient sources suggests so. For example, Livy's Cato expressed outrage at the female lobby against the lex Oppia in 195: men were allowing women to engage (capessere) in the res publica and almost to be involved in the Forum, public meetings (contiones), and assemblies (comitia)! 5 In response to Cato, Livy's Valerius claimed that magistracies, priesthoods, triumphs, insignia, gifts, and war spoils could not be attained by women, and that elegance, adornment, and fine appearance were their insignia (insignia feminarum) and what they gloried in (gloriantur). ${ }^{6}$ Similarly, Appian's Hortensia delivered an oration in 42 demanding to know why women should pay a triumviral tax when they did not share in magistracy, honor, command, and the polity ( $\pi \circ \lambda(\tau \varepsilon i \alpha$, cf. res publica $){ }^{7}$ Finally, Valerius Maximus asserted that a woman had nothing to do with a public meeting (contio) according to ancestral custom and Gellius declared that women had no participation in assemblies (comitiorum communio). ${ }^{8}$ So far, so definitive.

Yet we know of women like Servilia, Iulia (mother of Marcus Antonius), Terentia, Clodia, Fulvia, Hortensia herself, and Octavia who loomed large in the politics of the last century of the libera res publica, as recent studies have demonstrated, particularly those of Rohr Vio. ${ }^{9}$ Even Syme, typically dismissive of women's roles in Roman society, acknowledged the political ambitions and interventions of Servilia, a woman he described as "possessed of all the rapacious ambition of the patrician Servilii and ruthless to recapture power for her house."10 As my opening examples indicate, Cicero himself was incited against

$5 \quad$ Livy $34 \cdot 2.11$.

$6 \quad$ Livy $34.7 \cdot 8-9$.

7 App. $B$ Civ. 4.33 .

8 Val. Max. 3.8.6; Gell. $N A$ 5.19.10.

$9 \quad$ Notable recent studies include: Culham 2004; Froese 2004; Treggiari 2007; 2019; Harders 2008; 2014; Skinner 2011; Brennan 2012; Lejeune 2012; Rohr Vio 2013; 2014; 2015; 2016; 2017; 2019; forthcoming; Lucchelli \& Rohr Vio 2014; Osgood 2014; Valentini 2014; Hopwood 2015; Borrello 2016; Buonopane 2016; Foubert 2016; Kunst 2016; Welch forthcoming. Earlier important studies: Münzer 1920; Balsdon 1962; Babcock 1965; Pomeroy 1975, 176189; Dixon 1983; 1988; Hillard 1983; 1989; 1992; Hallett 1984; Purcell 1986; Hemelrijk 1987; 1999; Tatum 1990; Evans 1991; Bauman 1992; Christ 1993; Dettenhofer 1994; Welch 1995; Glinister 1997; Laurence 1997; Cluett 1998; Günther 200o. See also Osgood in this volume.

10 Syme 1939, 23. For Syme's dismissive attitude: "Influences more secret and more sinister were quietly at work all the time - women and freedmen" (Syme 1939, 384) and "Women have their uses for historians. They offer relief from warfare, legislation, and the history of 
the Catilinarian conspirators by Terentia in 63 and relied heavily on her support during his exile in 58 . He was also acutely aware of Servilia's influence over Brutus in June 44, was-mirabile dictu - silenced by her during her consilium at Antium in the same month, and was unsurprised by her promise to alter a senatorial decree. These and other women seized political initiative and intervened in politics, that is, they were active participants in republican political culture. This chapter will chart the structures and practices of such female interventions in politics in the libera res publica.

Here I follow Dixon's expansive conception of politics in the Republic as "the pursuit and exercise of real power,"11 Hölkeskamp's reading of "political culture" in the Republic as "a discursive environment in which power is legitimated,"12 an "extraordinarily dense 'ensemble' of abstract values and ideology, rules and codes of behavior, cultural practices and civic rituals, images, messages, and meanings,"13 and Rosillo-López's finding that informal institutions (i.e. informal interactions, political customs, relationships, social networks, and unofficial channels, especially those unregulated by law) provided opportunities for female participation in politics in republican Rome. ${ }^{14}$ I define female interventions in politics as women's proactive engagement in the res publica, what Cicero and Livy termed rem publicam capessere, ${ }^{15}$ a definition akin to Kunst's for such interventions, namely "das Eingreifen in eine politisch aufgeladene Situation."16

Valerius Maximus links such female interventions with sedition (seditio) and violence (violentia) ${ }^{17}$ Were the female interventions of the first century, then, simply symptoms of civil war and dysfunction? Were they novel? In general, previous scholarship has regarded them so, or as a function of increased female "emancipation." ${ }^{18}$ Rohr Vio's statement is paradigmatic: "La ragione principale

ideas" (Syme 1986, 168). Cf. less dismissive comments on elite women and their power in Syme 1939, 444-445; 1964, 25-26.

11 Dixon 1983, 91.

12 Hölkeskamp 2010, 55 after Braddick 2005, 69.

13 Hölkeskamp 2010, 67 after Geertz 1973, 452. On republican political culture: Hölkeskamp 2010, esp. 53-75 and his contribution in this volume. Hölkeskamp builds on Meier 1966 and others.

14 Rosillo-López 2017, esp. 16-18, 221-222.

15 Cic. Att. 16.7.7; Cael. 72; De or. 2.106; Fam. 1.9.18; Off. 1.71-72; Sest. 23; Livy 3.69.5, 34.2.11.

16 "Intervention in a politically charged situation" (Kunst 2016, 200).

17 Val. Max. 3.8.6.

18 E.g., Syme 1939, 12, 444-445; 1964, 25, 135 (individual cases and emancipation); Pomeroy 1975, 149-189 (with precedents); Dixon 1983, esp. 91, 109-110; cf. 1988, 168-203 (on mothers and sons); Hillard 1983; 1989; 1992, esp. 39-40, 55; Evans 1991, 13-17 (with precedents); Bauman 1992, 6o-61; Christ 1993; Cluett 1998, esp. 67-68, 77-79; Culham 2004, esp. 155-158; 
dell' ingresso delle donne nella politica romana è ... l'eccezionalità del tempo dei conflitti intestini."19 Yet later Greek and Roman authors retrojected female interventions into their histories of early Rome: famous examples include the intercession of the Sabine women and that of Veturia and Volumnia with Coriolanus. ${ }^{20}$ Now, these examples may have been merely artificial precedents for female interventions in the first century, forged to provide an aura of authority and legitimacy for the novelty of "le iniziative femminili" of women like Terentia and Servilia, as suggested by Rohr Vio. ${ }^{21}$ But what if there were various structures and practices of such interventions that existed long before these women were born? According to Livy, there were several instances in the fourth and third centuries when female interventions (viz. benefactions) saved Rome from financial and military crises. ${ }^{22}$ Appian's Hortensia even invoked one of these instances in her oration against the triumviral tax in 42 , namely women's contributions from their jewelry ( $x o ́ \sigma \mu \circ)$ in the Second Punic War. ${ }^{23}$ Should we dismiss these as anachronistic fancies or as utterly exceptional?

Münzer himself recognized long ago that "die Frauen, die Mütter, Schwestern und Töchter" had decisively intervened (entscheidend eingegriffen) in "das Leben der männlichsten [!] Männer" in the Republic and he spoke of their complete involvement (die ganze Einmischung) in “die Kämpfe der Parteien." ${ }^{24}$ More recently, Kunst has mapped three "Formen der Intervention einflussreicher Frauen" in the Republic, ${ }^{25}$ comprising 1) interventions with female relatives (weiblichen Verwandten) of influential men, 2) interventions with male family members (Männer der Familie), and 3) interventions in public (Öffentlichkeit); these she envisions as part of a "Dimension weiblichen Handelns" she terms "Matronage." ${ }^{26}$ Broadly, Kunst interprets the majority of interven-

Froese 2004; Sumi 2004, 196-197; Milnor 2005, 1; Brennan 2012, esp. 363 (with precedents); Osgood 2014, esp. 47; Cenerini \& Rohr Vio (eds.) 2016 (and the contributions therein esp. Manzo 2016); Rohr Vio 2016; 2019, 7-16. Notable exceptions: Münzer 1920, esp. 244-245, 362-364, 426-427; Hemelrijk 1987; Dixon 2007, esp. 15-32; Valentini 2012; Kunst 2016; Treggiari 2019, esp. 217-220; Webb 2019; Welch forthcoming.

"The principal reason for the entry of women into Roman politics is ... the exceptional nature of the period of internal conflicts" (Rohr Vio 2019, 12).

20 Dion. Hal. Ant. Rom. 2.45-46, 8.39-54; Livy 1.13, 2.40 with, e.g., Hemelrijk 1987; Brown 1995;

Rohr Vio 2019, 13.

21 "Female initiatives" (Rohr Vio 2019, 13).

22 Livy 5.25.8-10, 5.50.7, 24.18.13-14, cf. 34.5.8-10.

23 App. $B$ Civ. 4.33. Probably the contributions from viduae in 214: Livy 24.18.13-14, 34.5.10.

24 "Women, mothers, sisters and daughters" ... "the life of the manliest men" ... "the struggles of the parties" (Münzer 1920, 426-427). Cf. Münzer 1920, 244-245, 362-364.

25 "Forms of intervention of influential women" (Kunst 2016, 197).

26 "Dimension of female action" (Kunst 2016, 199). 
tions as occurring in familial and marital contexts in the domus, for example, at events like the salutatio, convivium, and consilium, and through female networks built on family ties and collective religious activity. ${ }^{27}$ She also traces several examples of what she terms "public" intervention (öffentliche Intervention), including: 1) religious interventions, namely Quinta Claudia's role in the inaugural procession for Magna Mater in 204, the Vestal Claudia's intervention in her father Appius Claudius Pulcher's triumph in 143, Caecilia Metella's dream in 9o, and the Vestals' interpretation of an omen in 63;2) political interventions, notably the female lobby against the lex Oppia in 195 and Hortensia's oration of $42 ; 3$ ) pleas for mercy (Gnadengesuche), especially during the triumviral proscriptions; and, 4) the public, political activity of women like Fulvia. ${ }^{28}$ Kunst concludes that the majority of these interventions were in the form of a plea (die Bitte; cf. supplicatio) — a vital aspect of republican political culture for men and women,- - that such pleas could, at times, be framed as a demand (Aufforderung), and that interventions encoded as pleas were viewed as a legitimate form of social participation (gesellschaftlichen Teilhabe) for women. ${ }^{29}$ There were, then, many structures (female networks, domestic contexts) and practices (religious activity, pleas) of female interventions before Servilia.

But this image is somewhat inchoate, for pleas were not the only, nor necessarily the most important, practice of female interventions, nor was the domus always the primary structure for these. In this chapter, I outline and evaluate additional structures of female interventions, namely the ordo matronarum, matronal meetings, and religious roles, and their practices, namely intercession (including pleas), benefactions, and participation in family consilia. My primary focus will be on interventions by elite women (senatorial and to some extent equestrian), as these women possessed various resources (cultural, economic, social, and symbolic capital) that enabled them to participate in republican political culture, and as they were related by birth or marriage to the men who could hold magisterial offices and commands. ${ }^{30}$ Regarding economic capital, elite women could control substantial property, for example, the prop-

\footnotetext{
27 Kunst 2016, 200-205, esp. 200-201.

28 Kunst 2016, 205-209.

29 Kunst 2016, 209-213. Cf. Manzo 2016 who focuses on pleas and female voices in the first century and Rohr Vio 2019 who focuses on women and politics in the late Republic and locates their political actions in either private or public contexts and spaces.

30 On these women, see esp. Dixon 1983; 2007; Hemelrijk 1999; Culham 2004; Valentini 2012; Rohr Vio 2019; Treggiari 2019; Webb 2019; Welch forthcoming.
} 
erty in their dowries, ${ }^{31}$ inheritances, ${ }^{32}$ personal effects, ${ }^{33}$ and peculium, ${ }^{34}$ and were Roman citizens registered in the census; ${ }^{35}$ property (or the lack thereof) could greatly enable (or disable) their participation in public life. ${ }^{36}$ While elite women could not seek or hold magisterial offices and commands themselves, with their various resources they could influence and support (or undermine) the men who could. ${ }^{37}$ Cicero's evidence is clear: women like Terentia and Servilia could affect and effect the res publica. Moving beyond previous scholarship, I argue that their interventions were not novel, but a manifestation of a long tradition of women seizing political initiative. We will see that women proactively engaged in the res publica.

A word or two on source issues before we proceed. Apart from a letter attributed to Cornelia "mater Gracchorum," our surviving ancient textual sources attesting female interventions are primarily authored by elite males or by male authors writing for predominantly elite male audiences. Consequently, we are left with veiled representations of elite women, representations colored by elite male biases and concerns. Genre was closely entangled with these representations, that is, authors would employ various female stereotypes or stock characters depending on genre. Regardless of genre, male authors frequently interpreted female activity sexually, to the extent that sexuality plays a role in many representations, and was often used to vilify politically active elite women. ${ }^{38}$ For these and numerous other reasons, there are complex relationships and tensions between literary representation and the identities and lived experiences of elite (and other) women. ${ }^{39}$ Thus, great cau-

31 Dowries: e.g., Polyb. 18.35.6, 31.22.4, 31.27 with Evans 1991, 53-88; Saller 1994, 204-224; Treggiari 2002, 323-364, esp. 348-350.

32 Inheritances: e.g., Cato, fr. 158 ORF ; Polyb. 31.27.5; Lucil. fr. 519-520, 1350M; Cic. Verr. 2.1.107; Livy 39.9.7 with Champlin 1991, esp. 121-124; Pölönen 1999; Cantarella 2016, 422. Personal effects (res): e.g., Plaut. Amph. 928; Men. 8o1-804; Trin. 267; Polyb. 31.26; Lucil. 16.519-2oM; Dig. 32.100.2, 34.2.13, 34.2.30, 34.2.32.6 with Champlin 1991, 123; Berg 2002; Treggiari 2002, 446-447.

34 Peculium: e.g., Plaut. Cas. 193-202; Mostell. 253 with Treggiari 2002, 363, 381, 445-446. Cf. See Senatus consultum de Pisone patre 104-105 with Flower 1998, 164, 169.

35 Women, citizenship, and the census: Cic. Leg. 3.7; Livy 3.3.9; Per. 59; Dion. Hal. Ant. Rom. 4.15.6, 5.75.3, 9.25.2 with Hin 2008, 201-204; Northwood 2008, 258, esp. n. 5 .

$36 \quad$ E.g., Polyb. 31.26.6-8 with Walbank 1979, 503, 505, 510-511. I delve into these matters in a forthcoming chapter on impoverished senatorial women.

37 Cf. Yakobson in this volume on the non-elite influences on the formal initiatives of officeholders.

38 On these source issues, see esp. Hillard 1989; 1992; Dixon 2001, 16-25; 2004, 56-59, 69-70; Schultz 2006b, 6-9; Milnor 2009.

Dixon 2001, 16-25, esp. 24-25. 
tion is needed in approaching and assessing male-authored representations of female interventions in politics. Nevertheless, these do provide rich insight into how some men understood and (re)constructed elite women and their lives. The silences, stereotypes, and absences present in our primarily male-authored sources should not preclude women from a history of republican politics, for that would exclude many of the people who shaped Rome itself. Finally, I privilege contemporary republican sources (e.g., Polybius and Cicero) in an attempt to avoid the anachronism present in later sources. However, given the dearth of these, I will turn to later sources as well, for I assume these were not all manufactured ex nihilo and may still offer some details of individuals and events from at least the third century onwards. ${ }^{40}$ Instead of viewing these source issues as an insurmountable barrier, in this chapter I consider a wide variety of ancient textual sources and take up Richlin's proposition that women were necessarily participants in the cultural systems of Rome. ${ }^{41}$

The elite domus and villa were quintessential structures for women and politics, enabling various interventions, as Foubert, Kunst, Flower, and Rohr Vio have argued..$^{42}$ Therein Servilia planned the future of the res publica in her consilium of June 44. I do not discount their importance. But if we move outside of these for a moment and look elsewhere, a few other structures appear, including the ordo matronarum, matronal meetings, and religious roles.

\subsection{Ordo matronarum}

Elite married women were members of an organized social network, the order of married women (ordo matronarum), whose criteria for entry probably included marriage, high social position (rank), and wealth. ${ }^{43}$ This order com-

40 For similar perspectives: Fantham 2004; Bispham 2006, 32-40; Schultz 20o6b, 8-9.

41 Richlin 2014, 11-12. Slightly more pessimistic attitudes: Hillard 1989; 1992; Dixon 2001. Similarly optimistic attitudes: Culham 2004; Schultz 2006b; Dixon 2007 (shift in attitude); Milnor 2009; Richlin 2014; Treggiari 2019.

42 Foubert 2016; Kunst 2016, 198-205; Flower 2018; Rohr Vio 2019, 19-46.

43 Plaut. Cist. 22-26; Livy 10.23.10, 34.7.1; Val. Max. 5.2.1; 8.3.3; App. B Civ. 4.32-34 with Purcell 1986, 170, 179; Hemelrijk 1987; 1999, 11-12, 202; Bauman 1992, 82-83; Böels-Janssen 1993, 275-281; 2008, 38; Fantham 2011, 171-174; Valentini 2012, 44-81; Hopwood 2015 (without reference to the ordo); Webb 2019, 257-258. I have elsewhere theorized that the order may have comprised the wives of the privileged 1800 equestrians with a public horse (equites equo publico) in the middle Republic, for these numbers are remarkably close (1400 
prised at least 1400 wealthy married women by 42 , as attested by Valerius Maximus and Appian in their respective accounts of Hortensia's oration against the triumviral tax of 42; it was members of this ordo who selected Hortensia to speak for them. ${ }^{44}$ The earliest allusion to something akin to this ordo occurs in Plautus' Cistellaria, when the lena and mother of the meretrix Gymnasium compares her own order of freedwomen (or freedpersons) to a kind of network of highborn daughters (summo genere natae) and high-ranking married women (summatis matronae) who cultivate friendship (amicitiam colunt) and are joined together by it (eam iunctam bene habent inter se). ${ }^{45}$ While this is not secure evidence for the ordo, Plautus and his audience were clearly aware of networks of elite married women. Our earliest secure references to the activities of the ordo occur in Livy, when he links it with the foundation of the cult of Pudicitia Plebeia in 296 and with the female lobby against the lex Oppia in $195^{46}$ Valerius Maximus connects this same ordo with the legendary intercession of Veturia, Volumnia, and other married women with Coriolanus and the foundation of the temple of Fortuna Muliebris in ca. 488; similarly in his

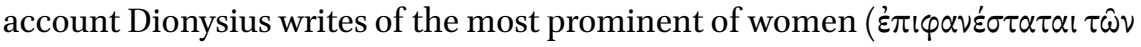

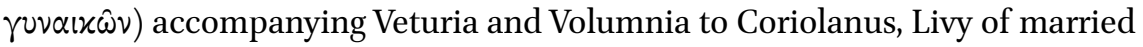

married women and 1800 equestrians with a public horse) and, if the triumviral tax of 42 was designed to make up a shortfall of 200,00o,ooo drachmae/denarii from the property of 1400 women, many of these women would have had property worth more than the late republican equestrian census qualification or above (100,0oo drachmae/denarii): App. B Civ. 4.32-33 with Webb 2019, 257 n. 3o; forthcoming. Note especially that when the triumvirs revised the tax, they imposed it upon 400 women and then all men who possessed more than 100,ooo drachmae/denarii: App. BCiv. 4.34. How the plebiscitum reddendorum equorum of ca. 129 may have affected the membership of the ordo is uncertain.

44 Val. Max. 8.3.3 (name: ordo matronarum); App. B Civ. 4.32-34 (membership and nature-

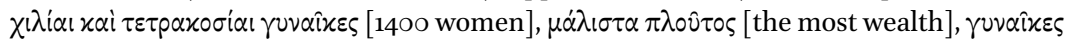

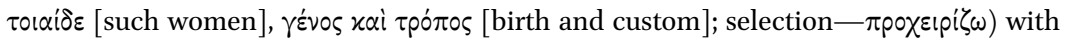
Hopwood 2015 .

45 Plaut. Cist. 22-26 with Fantham 2011, 157-174, esp. 169-174; Stockert 2012, 91. The ordo mentioned by the lena is one of freedwomen (or freedpersons): Plaut. Cist. 23 (hic ordo), 33 (noster ordo), 38 (nos libertinae sumus, et ego et tua mater, ambae) with Fantham 2011, 159, 169-174. Cf. collective activity by libertinae in 217: Livy 22.1.18 with Fantham 2011, 172. Plautus does not explicitly mention an ordo matronarum, but the comparison between the ordo of freedwomen/freedpersons and the highborn daughters and high-ranking matronae is suggestive, especially as the latter cultivate and are joined by amicitia. For an ordo libertinus/libertinorum in the Republic: Cic. Cat. 4.16; Phil. 2.3; Verr. 2.1.124; Cicero, Comment. pet. 29 with Treggiari 1969, 162-168; Ryan 1998, 146; MacLean 2018, 17, 94.

46 Ordo in 296: Livy 10.23.10 with Oakley 2005, 245-259. Pudicitia Plebeia episode: Palmer 1974, 123-125; Nathan 2003; Treggiari 2019, 20. Ordo in 196: Livy 34.7.1 with Briscoe 1981, 6o-62. Abrogation of lex Oppia and ordo: Hemelrijk 1987; Webb 2019; forthcoming. 
women meeting as a crowd (matronae frequentes coire) at Veturia's domus and a great company of women (mulierum agmen) accompanying her to Coriolanus, and Plutarch of the most eminent ( $\delta \circ \kappa \mu \omega \dot{\omega} \tau \alpha \tau \alpha)$ women-including Valeria who he describes as having glory ( $\left.\delta \delta^{\prime} \xi \alpha\right)$ and honor $(\tau \mu \eta \dot{\eta})$ in the city $(\pi \dot{\lambda} \lambda ı)$ approaching Coriolanus' mother and wife, although these authors do not mention an ordo explicitly. ${ }^{47}$

Members of this ordo and/or wealthy married women had particular privileges and status symbols, including unrestricted movement in Rome, the use of the two-wheeled carriage (carpentum) and the four-wheeled carriage (pilentum) for religious and secular purposes in Rome, the use of the insignia of ears/earrings (aurium insignia), the distinction of the fillet (vittae discrimen), gold trimmings/borders (aurea segmenta), purple clothing (purpurea vestis), and possibly funerary orations (laudationes). ${ }^{48}$ According to Diodorus Siculus, Livy, Valerius Maximus, and Plutarch, many of these were honors granted by senatorial decree to married women and/or the ordo for their interventions, notably for their intercession with Coriolanus and their benefactions during financial and military crises in the fourth century, namely a financial contribution for a votive donum for Delphic Apollo in 395 and a ransom for the Gauls in 390, all of which came from their jewelry. ${ }^{49}$ Whether or not these episodes and explanations are mere aetiological speculation, these authors projected the existence of a network of elite married women into Rome's distant past, a network distinguished by its privileges and status symbols, suggesting the antiquity of something akin to the ordo. Critically, the interventions of these married women were publicly honored: they were effective, legitimate, and laudable.

Once the existence of such a network (or networks) is acknowledged, we can entertain the possibility that it lay behind some of the collective actions (e.g., mourning, benefactions, religious activity, lobbies) of married women throughout the Republic, and was one of the central structures enabling their interventions. ${ }^{50}$

47 Val. Max. 5.2.1 (explicitly matronarum ordo). Cf. Dion. Hal. Ant. Rom. 8.39-54; Livy 2.40; Plut. Cor. 33-34 with Ogilvie 1965, 334.

48 Status symbols and privileges: Cic. De or. 2.44; Diod. Sic. 14.116.9; Livy 5.25.9, 5.50.7; Val. Max. 5.2.1; Plut. Cam. 8.3-4; De mul. vir. 1; Festus, Gloss. Lat. 142L, 225L, 282L; CIL VI 31075 with Hemelrijk 1987, 222-223, 229-230; 1999, 11; Hillard 2001; Berg 2002, 43; Hudson 2016; Webb 2019; forthcoming; Östenberg forthcoming.

49 Diod. Sic. 14.116.9 (Gauls); Livy 5.25.9 (Apollo), 5.50.7 (Gauls), 34.5.9 (Gauls); Val. Max. 5.2.1 (Coriolanus); Plut. Cam. 8.3-4 (Apollo); Zonar. 7.21 (Apollo) with Ogilvie 1965, 684, 741; Webb 2019; forthcoming.

E.g., for such collective actions in Livy alone: Livy 2.7.4, 2.16.7, 2.40.1, 3.48.8, 5.25.9, 5.50.7, 


\subsection{Matronal Meetings}

With this network in mind, two instances of organized matronal meetings in the Republic are worth (re)consideration. Firstly, Livy describes a coetus (meeting) of married women in 395, whose purpose was to consider a financial contribution for the votive donum for Delphic Apollo, as there was not enough gold in the public treasury to produce an adequate one; in this meeting, convened to consider the matter (matronae coetibus ad eam rem consultandam habitis), the married women promised gold to the military tribunes by a communal decree (communi decreto pollicitae tribunis militum aurum), and subsequently delivered all their (presumably gold) jewelry to the public treasury (omnia ornamenta sua in aerarium detulerunt). ${ }^{51}$ Secondly, Livy records another meeting of married women in 207, convoked on the Capitoline by the edict of a curule aedile (aedilium curulium edicto in Capitolium convocatae), again to discuss a financial contribution for a donum, in this case to expiate a prodigy (prodigium) concerning Iuno Regina that pertained to married women according to the haruspices. This meeting involved all married women living in the city of Rome or within ten miles thereof: this was no small affair! At this meeting, married women delegated twenty-five from among themselves (ipsae inter se quinque et viginti delegerunt) to whom they should bring a contribution from their dowry (stips ex dotibus); from these contributions a donum of a gold bowl (pelvis aurea) was made and carried to the Temple of Iuno Regina in the Aventine. ${ }^{52}$ What is striking about Livy's accounts of these meetings is that they suggest married women a) had the capacity to hold formal meetings without male oversight, b) had a collective decision-making process, c) had the authority to issue - presumably binding - communal decrees (decreta communia) pertaining to married women, ${ }^{53}$ and d) could delegate responsibility for important financial tasks to meeting attendees. ${ }^{54}$ In both instances, the Senate and magistrates respected these meetings and recognized their process and outcomes: I am reminded in both instances of senatorial consultation of sacerdotal collegia. Moreover, in the first instance of 395, a thankful Senate voted an honor

5.52.11, 6.4.2, 10.23.4-9, 21.62.8, 22.1.18, 22.7.7, 22.55.4-6, 22.56.4-5, 24.18.13-14, 25.12.15, 26.9.7-8, 27.37.7-10, 27.50.5, 27.51.9, 29.14.10-12, 34.1.5, 34.2.10, 34.5.3-10, 34.6.8-9, 15. Cf. Fantham 2011, 171-173.

51 Livy 5.25.8-9 with Weissenborn 1865, 312; Ogilvie 1965, 684 (with no comment on the coetus). Cf. Plut. Cam. 8.3-4; Zonar. 7.21.

$5^{2} \quad$ Livy 27.37.7-10 with Weissenborn 1863, 92-93; Boyce 1937; Hänninen 1999b, esp. 41-51; Schultz 2006b, 34-37, 44, 135, 144.

53 Cf. decretum commune in Livy 36.20 .3 , 37.6.2.

54 Cf. a meeting of the equestrians on the Capitoline and their delegation to the consuls and Senate in 58: Cass. Dio 38.16.2-3 with Hall 2014, 45 . 
(viz. issued a senatorial decree) for the married women for their munificence (honoremque ob eam munificentiam ferunt matronis), namely, that they might use four-wheeled carriages for religious rites and games and two-wheeled carriages for festal and non-festal days (ut pilento ad sacra ludosque, carpentisfesto profestoque uterentur). ${ }^{55}$ Such a decree to married women offers additional substantiation for the ordo matronarum. As with the ordo, the sources attest to the efficacy, legitimacy, and laudability of this structure (matronal meetings) of female intervention.

Beyond these two meetings, Livy recounts an earlier event in 217 when the Senate decreed that after money had been collected by married women, each contributing as much as was appropriate, they should bring it as a donum to the Temple of Iuno Regina and a lecisternium should be held (decretum est ... matronaeque pecunia conlata quantum conferre cuique commodum esset donum Iunoni reginae in Aventinum ferrent lectisterniumque fieret), and this collection suggests further meetings and organization. ${ }^{56}$ Additionally, the selection of Sulpicia by ten married women (themselves chosen by lot from a hundred married women) to dedicate a statue for Venus Verticordia ca. 216/215 (or perhaps earlier in 237 or 224) and the selection of Quinta Claudia for a leading role in the inaugural procession for Magna Mater in 204 feasibly entailed similar meetings and decrees. ${ }^{57}$ Pliny relates how this Sulpicia was the first to be judged the most

$55 \quad$ Livy $5.25 \cdot 8-9$.

56 Livy 22.1.17-18 with Weissenborn 1872, 151; Fantham 2011, 172.

57 Sulpicia: Val. Max. 8.15.12; Plin. HN 7.120; Solin. 1.126. Quinta Claudia: Cic. Cael. 34; Har. resp. 27; Livy 29.14.12; Plin. $H N$ 7.120. On these selections: Flower 2002, 162-166; Schultz 2006b, 144-145; Fantham 2011, 172-173; Webb 2019, 26o-261. The date of Sulpicia's selection is uncertain. Pliny's account in $H N 7.120$ (semel ... Sulpicia ... iterum ... Claudia) suggests it occurred prior to the selection of Quinta Claudia in 204. If Quintus Fulvius Flaccus, consul of 237, was Sulpicia's husband, as is generally supposed, then her selection feasibly occurred during one of his consulships in 237, 224, 212, and 209 or during his urban praetorships in 215 and 214: Münzer 1931, 817. A date ca. 216/215 is attractive, as Flaccus was co-opted into the pontifical college in 216, the Vestals Floronia and Opimia were convicted of stuprum and died in 216, Flaccus was urban praetor in 215, the temple of Venus Eryx on the Capitoline was dedicated in 215, and the lex Oppia was passed in 215: Livy 22.57.1-6 (Floronia and Opimia); 23.21.7 (co-optation of Flaccus); 23.30.13-14, 18 (Venus of Eryx, Flaccus as urban praetor); 34.1.1-3 (lex Oppia passed). Women and their actions were in focus ca. 216/215. Cf. Köves 1963, 340-342 (216); Pomeroy 1975, 179, 208; Gruen 1990, 26 n. 109 (216); Palmer 1997, 121-122 (ca. 215). Contra ca. 216/215, Livy does not mention the selection of Sulpicia in Books 21-30 (for 219 to 201). However, he may have mentioned it in his lost Book 20, perhaps in his account of the years 237 or 224, that is, for the years of Flaccus' first or second consulships. 237 is also an attractive date, as a Vestal Tuccia was condemned for incestum around that year: Livy Per. 20. Cf. Schultz 2006b, 200-201 n. 24; Fantham 2011, 172. For prosopographical details and pitfalls: Hillard 2014, 43-46. 
sexually virtuous woman by a resolution of the married women (pudicissima femina semel matronarum sententia iudicata est Sulpicia), suggesting again that married women had a collective decision-making process. ${ }^{58}$ These meetings, collection, and selections offer us a glimpse at matronal authority and power in the Republic, particularly in matters of religion and property..$^{59}$ Matronal meetings provide corroborating evidence for the existence of an organized social network like the ordo matronarum and, indeed, hint at some kind of matronal governing body. Later evidence from the Empire attests to a hierarchical assembly of women or married women (conventusfeminarum/matronarum) that met on the Quirinal, suggesting some structural continuity in female interventions between Republic and Empire. ${ }^{60}$ To borrow an expression from Dixon, DiLuzio, and Treggiari: these few instances are but "the tip of an iceberg." ${ }^{1}$ Married women must have met frequently in such meetings, discussed and debated numerous matters affecting themselves and the res publica, and issued communal decrees. We know the Senate, a meeting of senators, exercised power, but so too did matronal meetings.

\subsection{Religious Roles}

Women, especially elite ones, held numerous sacerdotal (priestly) and nonsacerdotal roles in the Republic, as demonstrated masterfully by Schultz and DiLuzio. ${ }^{62}$ Pace Livy's Valerius, women held sacerdotal public offices (sacerdotia), notably as the three flaminicae maiores (flaminica Dialis, Martialis, and Quirinalis, priestess of Jupiter, Mars, and Quirinus), the regina sacrorum (queen of the sacred rites), and the six virgines Vestales (Vestal virgins), all prominent and prestigious priesthoods. ${ }^{63}$ In particular, the patrician flaminica Dialis and the patrician and plebeian Vestales served as living exempla for other women, embodying ideal marital, religious, and sexual behaviors. ${ }^{64}$ Moreover, flaminicae, regina sacrorum, and Vestales (and perhaps the sacerdos Cereris, priestess of Ceres) seem to have offered sacrifices on behalf of the People (pro populo), a clear indication of their religious authority and capacity. ${ }^{65}$ Beyond priesthoods, women held many non-sacerdotal roles, participating prominently in regular

\footnotetext{
$5^{8} \quad$ Plin. $H N$ 7.120.

59 In these cases, probably res, personal effects, and dos, dowry.

6o Sen. De matrimonio fr. 13.49 Haase; Suet. Galb. 5; CIL VI 997 (Quirinal); SHA Heliogab. 4.3-4 (Quirinal) with Hemelrijk 1987, 230-231; Valentini 2012, 49-52.

61 Dixon 1983, 108; DiLuzio 2016, 239; Treggiari 2019, 218.

62 Schultz 2006b; DiLuzio 2016.

63 Livy 34.7.8. Priesthoods: DiLuzio 2016, esp. 17-68, 119-239; Webb 2o18, 68-7o.

64 Schultz 2006b, 141-143; DiLuzio 2016, 47-51, 152; Webb 2019, 26o.

65 Schultz 2006b, 135, 143; DiLuzio 2016, 28, 51-52, 68, 109-110.
} 
religious festivals, leading prominent public processions (before the People and with sacerdotes and magistrates), hosting rites, dedicating statues, and organizing dona, as I have mentioned earlier. ${ }^{66}$ Sacra publica, public religious rites, were a prominent domain of female action. ${ }^{67}$ Here I will not readdress the numerous roles and functions of priestesses and other women, but instead focus on key examples of female interventions enabled by their religious roles.

The Vestales engaged in numerous interventions in politics in the Republic, as Gallia and DiLuzio have argued. ${ }^{68} \mathrm{~A}$ few examples follow. Famously, the Vestal Claudia supported her father Appius Claudius Pulcher's illicit triumph in 143, interposing her body between a hostile plebeian tribune (inimicus tribunus plebei) and her father by embracing the latter (patrem complexa), blocking the former's actions with her bodily sanctity and religious authority, thence allowing her father to complete his triumph. ${ }^{69}$ The Vestal Licinia dedicated an altar, shrine, and ritual couch in a public place on the Aventine without the permission of the People (iniussu populi) in 123, which was a possible violation of the lex Papiria on such dedications of ca. 179-154; her dedication seems to have been politically motivated and was rapidly declared non sacrum by the pontifices and thence removed by the urban praetor Sextus Iulius Caesar. ${ }^{70}$ In ca. 69, Cicero recounts how the Vestal Fonteia embraced her brother Marcus Fonteius (akin to the Vestal Claudia), as a public sign of her support during his trial for repetundae and appealed to the fides of the judges and the Roman People (germanum fratrem complexa teneat vestramque, iudices, ac populi Romani fidem imploret); indeed Cicero warns the judges of the religious consequences and peril (periculosum) if they reject the supplication (obsecratio) of Fonteia, whose prayers (preces) kept them safe (salva): Fonteia had Vesta on her side. ${ }^{71}$ In 63 , a different Vestal Licinia, granted (concedere) her seat at some gladiatorial games to her relative and close friend (propinquus et necessarius) Lucius Licinius Murena, who was campaigning for the consulship of 62, and thereby visibly offered him her political support: this was Vestal endorsement. ${ }^{72}$ During the December rites for Bona Dea in 63 , hosted by Terentia at her and Cicero's domus, the assembled Vestales and married women witnessed an

\footnotetext{
66 Cf. Schultz 20o6b, 139-15o.

67 Webb 2019.

68 Gallia 2015, 77-82; DiLuzio 2016, 223-239.

69 Cic. Cael. 34 with Gallia 2015, 78; DiLuzio 2016, 225-228; Webb \& Brännstedt forthcoming. Cf. Val. Max. 5.4.6; Suet. Tib. 2.4.

70 Cic. Dom. 136-137 with DiLuzio 2016, 228-231. For the lex Papiria: Cic. Dom. 127-128 with Elster 2003, 353-354.

71 Cic. Font. 46-48 with Ridley 200o, 223; Gallia 2015, 78-79.

72 Cic. Mur. 73 with DiLuzio 2016, 231-232.
} 
omen ( $ๆ \mu \varepsilon \hat{i}$ v) after sacrifices (re-ignition of the ashes and bark on the altar), and the Vestales interpreted it as divine support for Cicero's severe approach to the Catilinarian conspirators; it was this interpretation that Terentia relayed to Cicero and with which she presumably incited him against the conspirators. ${ }^{73}$ These individual acts aside, the Vestales could also collectively intercede with magistrates on behalf of men, as they did for Caesar when he was proscribed by Sulla in 82, when by their intercession (along with that of his maternal relatives Caius Aurelius Cotta and Mamercus Aemilius Lepidus Livianus), he obtained a pardon (per virgines Vestales perque Mamercum Aemilium et Aurelium Cottam propinquos et adfines suos veniam impetravit). ${ }^{74}$ Furthermore, the Vestales could be consulted by the Senate along with the pontifices on religious matters (probably as members of the pontifical collegium), as Cicero indicates they were on the matter of Publius Clodius Pulcher's intrusion into the home of Caesar and Pompeia in the December rites for Bona Dea in 62 (rem ex senatus consulto ad virgines atque pontifices relatam); indeed the Vestales seem to have participated in the formulation and issue of the pontifical decretum wherein Clodius' intrusion was deemed nefas (idque ab iis nefas esse decretum), a decree which had profound political implications for the res publica, including Caesar's divorce of Pompeia. ${ }^{75}$ As is well-known, legal documents, money, and valuables could also be deposited for safety with the Vestales at the Temple of Vesta, as famously was Caesar's will and the Treaty of Misenum. ${ }^{76}$ By virtue of their religious roles, Vestales had enormous influence in the politics of the res publica and adroitly intervened on multiple occasions, even at the risk of their lives and reputations. ${ }^{77}$

Apart from this prestigious priesthood, married women themselves could intervene in politics due to their religious roles. Two examples illustrate this phenomenon well. Polybius recounts how Pomponia, mother of Publius Cornelius Scipio Africanus and Lucius Cornelius Scipio Asiagenus, engaged in a kind of religious lobby on behalf of Asiagenus for his aedilician electoral campaign (ca. 196, but the implied date in the account is earlier); Pomponia reputedly went around to the temples and sacrificed to the gods on his behalf $(\pi \varepsilon p l-$

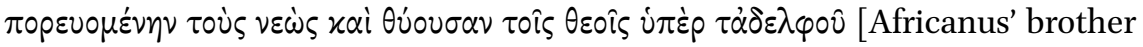

\footnotetext{
73 Plut. Cic. 20.1-3 with DiLuzio 2016, 232-234. Cf. Cass. Dio 37.35.4.

74 Suet. Iul. 1.2 with Ridley 200o, 223; DiLuzio 2016, 234-235. Cf. Vell. Pat. 2.41.2; Plut. Caes. 1.

75 Cic. Att.1.13.3 with Johnson 2007, 158-16o; Gallia 2015, 112; DiLuzio 2016, 89, 212-213. Cf. Cic. Har. resp. 37; Plut. Caes. 10; Cic. 28-29. For the Vestales as members of the pontifical collegium: DiLuzio 2016, 119-153, 186, esp. 119, 131, 141, 152, 186.

76 Caesar's will: Suet. Iul. 83.1. Pact of Misenum: App. B Civ. 5.73; Cass. Dio 48.37.1. Deposition: DiLuzio 2016, 236-238.

DiLuzio 2016, 238-239.
} 


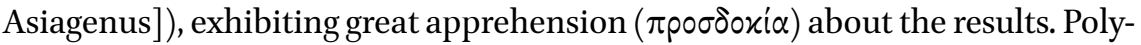
bius' also represents Pomponia as hoping that both Asiagenus and Africanus would attain the aedileship. ${ }^{78}$ While Polybius' account contains some problems, namely errors regarding the implied dates of Asiagenus' and Africanus' aedileships and the brothers' respective ages, Polybius clearly demonstrates that (he thought) at least one elite mother was heavily engaged and invested in her sons' political careers. Here we can imagine that Pomponia was not only seeking divine support, but leveraging and mobilizing her networks, perhaps the ordo matronarum itself. Around a century later, in 9o, during the Social War, Caecilia Metella, daughter of Quintus Caecilius Metellus Balearicus, had a dream that resulted in the restoration of the Temple of Iuno Sospita (in Rome or Lanuvium - location uncertain) by senatorial decree (Caeciliae Q. filiae somnio modo Marsico bello templum est a senatu Iunoni Sospitae restitutum), according to Cicero who cites the authority of Sisenna. ${ }^{79}$ Obsequens, in his summary of Livy's lost account of 9o, recounts details of the dream, namely that Iuno was fleeing (profugiens) her temple, because her precincts were being foully desecrated (immunde sua templa foedarentur); reputedly the temple had been defiled by the filthy and vile bodily ministrations of married women (aedem matronarum sordidis obscenisque corporis coinquinatam ministeriis) and there was even a dog and her litter under the statue of the goddess (in qua etiam sub simulacro deae cubile canis cum fetu erat); supposedly Caecilia persuaded the goddess to remain with her prayers (preces), cleaned the temple (commundare), and thereafter supplicationes were held and the temple restored. ${ }^{80}$ Sensational details aside, the Senate's response to Caecilia's dream indicates their acknowledgement of her religious authority and capacity, feasibly gained through her regular participation in religious activity for Iuno and other deities: her dream restored a temple. If Obsequens' (or Livy's) details are not entirely fictive, presumably the Senate trusted Caecilia's account of the purported practices of married women too. As Schultz has argued, the Senate treated Caecilia and her dream with the greatest seriousness, indicating their respect for elite women and the political significance of the dream during the Social War. ${ }^{81}$

These various examples indicate that religious roles enabled priestesses and other (particularly elite) women to intervene in politics, on an individual and

78 Polyb. 10.4.4-8 with Walbank 1967, 199-200; Webb 2017, 158-159.

79 Cic. Div. 1.99 with Hänninen 1999a; Schultz 2006a; 2006b, 26-28, 40, 42, 44. Cf. Cic. Div. 1.4; Iul. Obseq. 55 .

8o Iul. Obseq. 55 with Hänninen 1999a; Schultz 20o6a; 2006b, 26-28, 40, 42, 44; Flower 2015, 311-314; Kragelund 2018.

81 Schultz 2006a; 2006b, 27-28. Cf. similarly Flower 2015, 311-314. 
collective basis. Cicero's account of the Vestal Fonteia provides one possible answer for why the Senate and others accepted such interventions: women, priestesses and others, propitiated the immortal gods with their prayers, hands outstretched on behalf of the People, thence the safety of Rome was in these same hands. ${ }^{82}$ Who, then, would dare reject their supplication?

Outside of the domus, the ordo matronarum, matronal meetings, and religious roles provided women with numerous possibilities for interventions in politics. In general, our sources represent these structures as effective and legitimate, and, on occasion, laudable. While women could not be magistrates, these structures-and probably others-enabled them to engage with these same magistrates and effect significant change. Of note are the decreta issued at a matronal meeting and by Vestales along with the pontifices: these mirror the consulta of the Senate and decreta of sacerdotal collegia, suggesting the formal, institutional nature of female structures, matronal and sacerdotal. But this is just the apex of the iceberg. By turning now to the practices enabled by these and other structures, we shall glimpse a little more.

Practices

Kunst has argued that "die Bitte" was the primary practice of female interventions in politics in the Republic. Certainly, some interventions in politics took the form of pleas or supplications, particularly in the domus with female relatives of influential men or with male relatives or before magistrates and judges. Yet the domus, the ordo, matronal meetings, and religious roles enabled more than just pleas. In what follows, I outline three practices of female interventions emergent from, or attendant on, these structures, including intercession (encompassing pleas and more), benefactions, and participation in family consilia.

\subsection{Intercession}

Female intercession - women interceding on behalf of others-is intertwined with the history of the res publica. Three examples of intercession that are not just pleas follow, for these broaden our understanding of the practices of female interventions.

I begin with the account of Veturia and Volumnia's legendary intercession with Coriolanus, which feasibly goes back to Fabius Pictor, as he was one of

82 Cic. Font. 48. 
Livy's sources for his account. ${ }^{83}$ According to Livy, it was not Roman envoys (legati) or priests (sacerdotes) who moved Coriolanus to abandon his siege of Rome in ca. 488, but his own mother Veturia and wife Volumnia, who advanced to meet him in a company of women (mulierum agmen). ${ }^{84}$ Regarding the company, Livy writes that these women were defending (defendere) the Urbs with their prayers (preces) and tears (lacrimae). ${ }^{85}$ Prior to their delegation, elite married women had reputedly gathered (coire) at the domus of Veturia and Volumnia, led perhaps by a Valeria, presumably requesting their intercession with Coriolanus, as in Dionysius', Plutarch's (with alternate names for Coriolanus' mother and wife), and Appian's later accounts. ${ }^{86}$ Here we catch a glimpse of these authors' understanding of the practices of a female network like the ordo and their matronal meetings. When Coriolanus noticed his mother in the company of women, he approached her for an embrace. At this point, her prayers changed to anger (in iram ex precibusversa). Rather than pleading with him, she rejected his embrace and reproached him in an oration full of rhetorical questions and emotionally charged statements: did he come as an enemy (hostis) or a son (filius); is she a captive (captiva) or a mother (mater) in his camp (castrum); has her long life (longa vita) and unhappy old age (infelix senecta) led her to see her son as an exile (exsul) and enemy; will he devastate this land (terra) that bore (gignere) and nourished (alere) him; did his anger (ira) not fall when he entered the territory ( fines); when he saw Rome did it not come to mind (succurrere) that his domus, penates, mother, wife (coniunx), and children (liberi) were within these walls (moenia); had she no son, she would have died a free woman (libera) in a free country (libera patria); nothing was more repulsive (turpius) or more miserable (miserius) for her; even though she was most miserable (miserrima), it would not be for long (i.e. she would die soon); and if Coriolanus continued only an untimely death (immatura mors) or a long slavery (longa servitus) awaited her. ${ }^{87}$ Livy represents this speech and the subsequent embraces of his wife and children, along with the tears (fletus) and lamentation (comploratio) of the company of women for their country (patria) as breaking or defeating ( frangere) Coriolanus. ${ }^{88}$ Veturia's intercession was not a plea per se, but a reproach and dissuasion that centered Coriolanus' family,

\footnotetext{
83 FRHist 1 F16 = Livy 2.40.10-11 with Ogilvie 1965, 334-335; Cornell et al. (eds.) 2013, 33.

84 Livy 2.40.3 with Ogilvie 1965, 334-335.

85 Livy 2.40 .2 with Ogilvie $1965,334-335$.

86 Livy 2.40.1 with Ogilvie 1965, 334-335. Cf. Dion. Hal. Ant. Rom. 8.39-54; Plut. Cor. 33-37; App. Ital. 5.7-13.

87 Livy 2.40.5-9 with Ogilvie $1965,334-335$.

88 Livy 2.40 .9 with Ogilvie $1965,334-335$.
} 
familial roles, emotional ties, and her own emotions. ${ }^{89}$ Now, I am not arguing that this speech (or even the episode) is in any way historical. Instead, I suggest that here we find a model of female intercession characterized by reproach and dissuasion, a model recognized by Livy in his day, and one we find at work in at least two other intercessions.

Perhaps the most compelling evidence for such intercessions is the letter(s) of Cornelia "mater Gracchorum" to her youngest son the future plebeian tribune Caius Sempronius Gracchus, wherein she aims at dissuading him from his political goals and competing for the plebeian tribunate before her death. Two reputed excerpts from her letter(s) survive in the manuscripts of Cornelius Nepos (fr. 59 Marshall). The date and authorship of these excerpts is not secure: there is considerable scholarly disagreement over whether they are Cornelian and/or post-Gracchan propaganda and over whether they are from the same letter or separate letters by the same or different hands. ${ }^{90}$ Despite these disagreements, scholars tend to date them stylistically to the late second century or to ca. 124 before Caius Sempronius Gracchus' first plebeian tribunate in 123, that is, when Cornelia was a widow. ${ }^{91}$ The excerpts are worth examining, for they offer us a potent example of how one elite woman engaged - or was represented as engaging - in the res publica:

\section{[First excerpt]}

You will say that it is beautiful to take vengeance on personal enemies (inimici). This does not seem greater nor more beautiful to anyone than it does to me, but only if it is possible to pursue this with the res publica unharmed. But since that cannot be done, may our personal enemies not perish for a long time and for the most part, and may they remain as they are now, rather than that the res publica be cast down and perish ...

\section{[Second excerpt]}

I would dare to swear a formal oath that, apart from those who killed Tiberius [Sempronius] Gracchus, no personal enemy has delivered so

$89 \quad$ Hallett 2018, 314.

$90 \quad$ For recent discussion and bibliography on the Cornelian letter(s), see Courtney 1999, 135139; Hemelrijk 1999, 185-188; Hallett 2002, 13-24; 2018; Dixon 2007, 24-32; Roller 2018, 197-232.

91 Style: Hemelrijk 1999, 185-188; Dixon 2007, 27-28. Date of ca. 124: Courtney 1999, 136; Hallett 2002, 15. The date is controversial and I find attractive the putative suggestion of Lea Beness and Tom Hillard that 129 might serve as an appropriate date for the actual composition of such an impassioned letter or for the dramatic context to which it was ascribed. I will not expand on their arguments for that date here. 
much trouble and so much hardship to me as you have because of these things; [you] who ought to bear the part of all the children I have ever had, and to take care that I should have the least anxiety in my old age, and that whatever you did, you would wish to please me the most, and that you would consider it nefas to do greater things against my judgment, especially to me, to whom a little part of life remains. Cannot even such a short span [of life] relieve [me] from you opposing me and casting down the res publica? What end will there be finally? When, if ever, will our family cease being insane? When, if ever, can a measure be set on this matter? When, if ever, will we cease from troubles, desist from both having and causing them? When, if ever, will it [the family] truly feel shame for disturbing and perturbing the res publica? But if this cannot possibly happen, seek the tribunate when I am dead; as for me, do what will please you, when I will not perceive it. When I have died, you will sacrifice to me as a parent and you will invoke the parent of the gods/parent god. ${ }^{92}$ At that time, will it not shame you to seek prayers of those gods, whom, while living and present, you considered abandoned and forsaken? May Jupiter himself not permit you to persevere in this, nor permit such madness to enter your mind. And if you persevere, I fear that, by your own fault, you may receive such hardship throughout your whole life that at no time would you be able to please yourself. ${ }^{93}$

92 The identity of the deum parens or deus parens is uncertain, perhaps Jupiter (deum parens) or Africanus or Cornelia (deus parens): Walbank 1985, 122-123; Courtney 1999, 138; Hallett 2002, 17; 2010, 36o-361; 2018, 316.

93 Nep. fr. 59 Marshall: dices pulchrum esse inimicos ulcisci. id neque maius neque pulchrius cuiquam atque mihi esse videtur, sed si liceat re publica salva ea persequi. sed quatenus id fieri non potest, multo tempore multisque partibus inimici nostri non peribunt atque, uti nunc sunt, erunt potius quam res publica profligetur atque pereat. ... verbis conceptis deierare ausim, praeterquam qui Tiberium Gracchum necarunt, neminem inimicum tantum molestiae tantumque laboris, quantum te ob has res, mihi tradidisse; quem oportebat omnium eorum, quos antehac habui liberos, partis eorum tolerare atque curare, ut quam minimum sollicitudinis in senecta haberem, utique quaecumque ageres, ea velles maxime mihi placere, atque uti nefas haberes rerum maiorum adversum meam sententiam quicquam facere, praesertim mihi, cui parva pars vitae restat. ne id quidem tam breve spatium potest opitulari, quin et mihi adversere et rem publicam profliges? denique quae pausa erit? ecquando desinet familia nostra insanire? ecquando modus ei rei haberi poterit? ecquando desinemus et habentes et praebentes molestiis desistere? ecquando perpudescet miscenda atque perturbanda re publica? sed si omnino id fieri non potest, ubi ego mortua ero, petito tribunatum; per me facito quod lubebit, cum ego non sentiam. ubi mortua ero, parentabis mihi et invocabis deum parentem. in eo tempore non pudebit te eorum deum preces expetere, quos vivos atque praesentes relictos atque desertos habueris? ne ille sirit Iuppiter te ea perseverare, nec tibi tantam dementiam venire in animum. et si perseveras, vereor ne in omnem vitam 
In these excerpts, Cornelia (or "Cornelia") demonstrates her deep knowledge of Roman politics, her concern for the safety and stability of the res publica (mentioned four times), her rejection of zero-sum vengeance on personal enemies, and her ability to reproach and influence her son on political matters. Besides the abundance of highly charged emotional language, these excerpts are rich in religious, legal, and political language (e.g., inimici, res publica, deierare, verba concepta, nefas, sententia, petere, parentare, invocare, deus, preces, di, Iuppiter), indicating her reputed knowledge of those areas. ${ }^{94}$ Notably, Cornelia foregrounds religion: her religious roles affected her form of dissuasion. These excerpts reveal that at least one elite woman - and by inference many more-shared (or was represented as sharing) the political struggles of her male relatives and was deeply engaged in their public lives. Based on the similarity of the rhetorical questions and themes, Hallett has argued for some intertextuality between Cornelia's letter and Veturia's speech in Livy (cf., e.g., inimicus and hostis, senecta, res publica and patria, hardship and misery). ${ }^{95}$ Certainly, Veturia and Cornelia are both represented as interceding with their sons through reproach and dissuasion. Even if the excerpts are not genuine, they indicate that an elite woman was expected to engage in the res publica and to wield influence over her son(s). In the first excerpt, Cornelia refers twice to the family's personal enemies, a highly suggestive allusion to politics, for personal enmities were forged through politics. ${ }^{96}$ The second excerpt is also suggestive: here Cornelia outlines the trouble and hardship that Caius Sempronius Gracchus was causing her and admonishes him for not reducing her anxiety in her old age, for not trying to please her, for not considering it nefas to pursue his political goals against her judgment, and for opposing her. Moreover, she indicates she did not want to perceive the results of his political goals, which included potential damage to her and to the res publica itself. Clearly, Cornelia cared deeply about the res publica. Cornelia's admittedly unsuccessful attempt here to dissuade Caius Sempronius Gracchus from his political goals (zero-sum vengeance, tribunate) is akin to her successful dissuasion of his legislative pursuit of Marcus Octavius, one of the family's personal enemies, a dissuasion effected through her successful request he withdraw his rogatio (lex?)

tantum laboris culpa tua recipias, uti in nullo tempore tute tibi placere possis. See Courtney 1999, 135-139; Hallett 2002; 2010, 357-364; 2018.

94 Cf. Courtney 1999, 135-139.

95 Hallett 2002, 19-20; 2018, 313-314.

96 Caius Sempronius Gracchus, competition, and personal enmity: Epstein 1987, 2, 23, 115116. 
Sempronia de abactis of $123 .{ }^{97}$ Beyond such dissuasion, various other sources testify to Cornelia's influence over her sons' education, political advice, and interventions in their political careers. ${ }^{98}$ Plutarch recounts that Cornelia often reproached ( $\delta v \varepsilon 1 \delta \zeta \zeta \omega)$ her sons, because the Romans still addressed her as the mother-in-law ( $\pi \varepsilon v \theta \varepsilon \rho \alpha \dot{)}$ ) of Publius Cornelius Scipio Aemilianus, and not the mother ( $\left.\mu \eta^{\prime} \tau \eta \rho\right)$ of the Gracchi. ${ }^{99}$ Such a reproach suggests, along with the other evidence, that Cornelia was proactively engaged in her sons' public lives and in the res publica.

Finally, I return to Hortensia and her intercession with, and oration before, the triumvirs (Lepidus, Marcus Antonius, Caesar Divifilius) on the matter of the triumviral tax on the 1400 members of the ordo matronarum in 42. Appian's Hortensia opens her oration by recounting the failure of the elite married

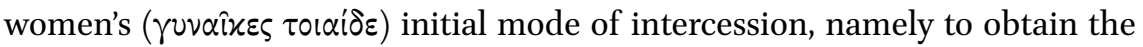
support of all the triumvirs' female relatives, for they were successful with Octavia and Iulia (mother of Marcus Antonius), but not with Fulvia. Indeed, they were ill-treated $(\pi \dot{\alpha} \sigma \chi \omega)$ by Fulvia and Hortensia explains that this forced ( $\sigma \nu v \omega \theta \dot{\varepsilon} \omega)$ them to the forum ( $\dot{\alpha} \gamma \circ \rho \alpha \dot{\alpha})$. The ordo had failed to mobilize support from within. Her oration swiftly pivots to a reproach of the triumvirs for depriving ( $\dot{\alpha} \varphi \alpha\left\llcorner\varepsilon^{\prime} \omega\right)$ the women of their fathers, sons, husbands and brothers, and for now attempting to additionally deprive $(\pi \rho \circ \sigma \alpha \varphi \alpha i p \varepsilon \omega)$ them of their property $(\chi \rho \hat{\eta} \mu \alpha)$, which would reduce them to a condition unworthy $(\dot{\alpha} \nu \alpha \dot{\xi} \iota \alpha)$ of

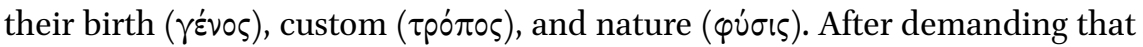
women be proscribed ( $\pi p \circ \gamma p \alpha \dot{\varphi} \varphi \omega)$ if they had wronged the triumvirs, Appian's

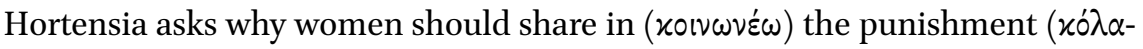
$\sigma / \zeta)$ if they had not partaken ( $\mu \varepsilon \tau \varepsilon \dot{\varepsilon} \chi \omega)$ in the wrongdoing ( $\alpha \dot{\delta}(x \eta \mu \alpha)$, especially if they had not voted any of the triumvirs a public enemy ( $\pi \circ \lambda \varepsilon \dot{\varepsilon} \mu \varsigma)$, nor torn

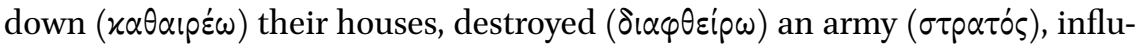
enced $(\dot{\varepsilon} \pi \dot{\alpha} \gamma \omega)$ them against each other, nor prevented $\left(\kappa \omega \lambda \nu^{\prime} \omega\right)$ them obtaining

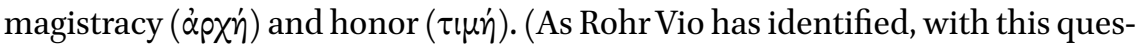
tion Hortensia dissociated the 1400 married women from their husbands and male relatives, many of whom committed these same acts against the Caesari-

97 Dissuasion: Diod. Sic. 34/35.25.2; Plut. C. Gracch. 4.2-3 with Epstein 1987, 115-116; Dixon 2007, 11; Beness \& Hillard 2013, 63-64. On the rogatio (lex?) Sempronia de abactis of 123: Rotondi 1912, 308. Plutarch's version of the events in Plut. C. Gracch. 4.3 suggests a rogatio

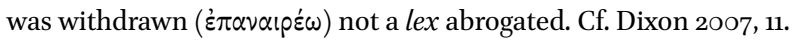

98 Cornelia and her sons' education: Cic. Brut. 104, 211; Quint. Inst. 1.1.6; Tac. Dial. 28.4-6; Plut. Ti. Gracch. 1.4-5; Jer. Ep. 107.4.6 with Dixon 2007, 18, 24; Beness \& Hillard 2013, 63. Political advice and intervention: Nep. fr. 59 Marshall; Diod. Sic. 34/35.25.2; Plut. C. Gracch. 4.2-3; 13.2; Ti. Gracch. 8.5 with Beness \& Hillard 2013, 63-65.

Plut. Ti. Gracch. 8.5. 
ans; Hortensia herself was linked affinally to Marcus Porcius Cato and the Caesaricide Marcus Iunius Brutus. Here Hortensia seems to have claimed, perhaps disingenuously, that she and the other women were uninvolved in these "male" actions. $\left.{ }^{100}\right)$ As mentioned earlier, Hortensia then asks why women should pay a tax when they did not not share in ( $\mu \varepsilon \tau \varepsilon \chi \chi \omega)$ magistracy $(\dot{\alpha} \rho X \dot{\eta})$, honor $(\tau \mu \dot{\eta})$, command ( $\left.\sigma \tau \rho \alpha \tau \eta \gamma^{\prime} \alpha\right)$, and the polity $\left(\pi \circ \lambda ı \tau \varepsilon^{\prime} \alpha\right)$. After reminding the triumvirs of female contributions in the Second Punic War, she asks what the triumvirs' fear $(\varphi \dot{o} \beta \circ \varsigma)$ is for the country ( $\pi \alpha \tau p^{\prime} \zeta$ ), claims that women will not be inferior to their mothers when it comes to the preservation ( $\sigma \omega \tau \eta p i \alpha)$ of the same coun-

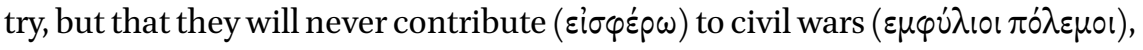
nor assist $(\sigma u \mu \pi \rho \dot{\alpha} \sigma \sigma \omega)$ the triumvirs against each other. The oration closes with

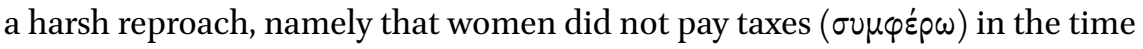
of Caesar or Pompeius, nor did Marius or Cinna compel ( $\dot{\alpha} v \alpha \gamma x \dot{\alpha} \zeta \omega)$ them to

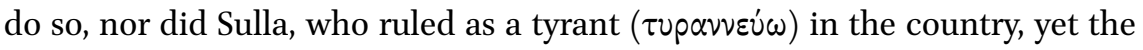
triumvirs were saying they were establishing $\left(\kappa \alpha \theta^{i} \sigma \tau \eta \mu l\right)$ the polity. ${ }^{101}$ Ergo, the triumvirs were worse than tyrants. Despite their resultant anger, the triumvirs reduced the number of women taxed from 1400 to 400 . Hortensia's oration was successful. ${ }^{102}$ As Hopwood has argued, Hortensia's oration amounts to a sustained criticism of not just the triumviral tax, but also their proscription edict and legitimacy itself. ${ }^{103}$ In many ways, this oration, Hortensian or otherwise, bears similarities to Veturia's oration and Cornelia's letter(s), full as they are with reproach, rhetorical questions, and themes of family, familial roles, the country (patria, $\pi \alpha \tau p i \varsigma)$, and the res publica $(\pi \circ \lambda i \tau \varepsilon i \alpha)$. Even if Hortensia claimed women did not share in the polity, these three elite women were all (represented as being) proactively engaged in the res publica. Even more importantly, Hortensia's oration questions the nature of the res publica under the triumvirs, revealing her own claim to superior knowledge and legitimacy. In hindsight, the actions of Hortensia and the ordo in 42 could be interpreted as vestiges of the libera res publica (soon-to-be amissa): their claims to authority and legitimacy were far more traditional than those of the triumvirs.

Numerous additional examples of female intercession in the Republic exist, many of which Kunst and Rohr Vio have enumerated, ${ }^{104}$ and many of which

\footnotetext{
100 Rohr Vio 2019, 192-193. Hortensia's affinal relations: Zmeskal 2009, 135-136, 256. Her husband Quintus Servilius Caepio adopted Marcus Iunius Brutus.

101 App. B Civ. 4.32-33 with Hopwood 2015, esp. 309-312.

102 App. $B$ Civ. $4 \cdot 34$.

103 Hopwood 2015, 311-312.

104 Kunst 2016; Rohr Vio 2019.
} 
were pleas, notably that of Iulia, mother of Marcus Antonius, ${ }^{105}$ Tertia Mucia, wife of Cnaeus Pompeius Magnus and Marcus Aemilius Scaurus, ${ }^{106}$ and that of the addressee of the laudatio Turiae. ${ }^{107}$ I will not address them here. Beyond pleas, the three examined examples indicate that female intercessions could take the form of a reproach or dissuasion, and that this was recognized by Livy, the author of the Cornelian letters, and Appian. Moreover, in the cases of Veturia and Hortensia, the ordo and matronal meetings feasibly enabled these intercessions, while Cornelia's maternal and religious roles enabled hers. Such practices were political and powerful.

\subsection{Benefactions}

As we have seen, female benefactions occurred throughout the res publica. The ordo matronarum, matronal meetings, and religious roles were intertwined with such benefactions, for these structures provided a framework for, and enabled the organization of, collections and dedications. Women engaged in both private and public benefactions, although public benefactions appear to have been limited to some degree to the religious sphere. ${ }^{108}$

One of the earliest examples of such benefactions is the legendary benefaction by the Vestal Gaia Taracia/Fufetia of the Campus Tiberinus/Martius to the Roman People in ca. 449, reported by Pliny, Plutarch (naming her as Tarquinia), and Gellius. ${ }^{109}$ For her benefaction, Pliny reports the Senate voted (decreed) her the honor of a statue, which she could place wherever she wished, while Gellius, drawing on antiquae annales, suggests a lex Horatia was passed that granted her many honors, particularly the right of giving testimony and the right to withdraw from her priesthood and marry at the age of forty. ${ }^{110} \mathrm{Gel}-$ lius explicitly states these honors were thanks (gratia) for her munificence (munificentia) and benefaction (beneficium). Now these accounts must be aeti-

105 For example, Iulia's successful intercession for her brother Lucius Iulius Caesar when he was proscribed in 43: Plut. Ant. 20.5-6; App. B Civ. 4.37 with Kunst 2016, 208; Rohr Vio 2019, 194-196.

106 For example, Tertia Mucia's successful intercession for her son Marcus Aemilius Scaurus after Actium presumably ca. 31/30: Cass. Dio 51.2.5 with Welch 2012, 301; Kunst 2016, 204; Rohr Vio 2019, 157 n. 45. Cf. her crucial role in facilitating the negotiations at Dicaearchia/ Puteoli in 39 between her son Sextus Pompeius Magnus Pius and Marcus Antonius and Caesar Divifilius: App. B Civ. 5.69, 72 with Welch 2012, 240, 248; Kunst 2016, 204; Rohr Vio 2019, 157 .

107 CIL VI 1527 with Osgood 2014.

108 Dixon 2001, 100-112; Schultz 2006b, 57-69.

109 Plin. $H N$ 34.25; Plut. Pop. 8.7-8; Gell. NA 7.7.1-4 with Flach 1994, 225-227.

110 Plin. $H N$ 34.25. 
ologies for Vestal privileges, but they clearly foreground and laud female benefactions, and retroject them into the early res publica. ${ }^{111}$ Similarly, benefactions are the reputed reason for the Senate granting elite married women and/or the ordo matronarum their privileges and status symbols, as mentioned previously. Female benefaction was honored and rewarded, particularly when it benefited the res publica.

Departing from these aetiologies, we find clearer evidence of the existence and prominence of female benefactions in Plautus, a republican inscription, Cicero, and Livy. In a paradigmatic - if comically inappropriate-statement of the normative virtues of a married woman in Plautus' Amphitruo, Alcmene claims that she does not consider what is called her dowry (dos) to be her dowry, but instead sexual virtue (pudicitia), shame (pudor), restrained desire (sedata cupido), fear of the gods (deum metus), love for her parents (parentum amor), harmony with her relatives (cognatum concordia), and that she is obedient (morigera) to her husband, munificent (munifica) to the good, and helpful (prosim) to the honest. ${ }^{12}$ The latter two are relevant here: benefactions are framed as characteristically positive and laudable for married women.

A ca. 100-50 republican inscription from Rome attests to a significant benefaction of a Publicia and her husband Cnaeus Cornelius: they built (or restored) a temple (aedes) of Hercules and its door (valvae), adorned it (expolire), and restored an altar (ara) sacred to Hercules with both her and her husband's money. ${ }^{113}$ The inscription foregrounds Publicia and her benefaction and indicates how women might use their religious roles and resources to shape the cityscape of the res publica itself. We saw earlier in Cicero's account of the Vestal Licinia and her abortive dedication of 123 that such benefactions could be highly political, and that not all were accepted by the Senate, but, in this case, Publicia succeeded.

Cicero offers further examples of female benefactions, notably of the aforementioned Caecilia Metella's protection of, and provision for, Sextus Roscius in 8 o, a kind of private benefaction. Caecilia provided the desperate, impoverished Roscius with refuge and protection in her domus from Sulla's powerful freedman Lucius Cornelius Chrysogonus and Roscius' own relatives, along with a bodyguard (praesidium), nourishing (ali), and clothing (vestiri). ${ }^{114}$ In his defense of Roscius, Cicero lauds Caecilia as an exemplum of old-fashioned

\footnotetext{
111 Cf. Flach 1994, 226.

112 Plaut. Amph. 839-842 with Christenson 2000, 274.

113 CIL VI 30899 with Schultz 2006b, 57-69; Kragenlund 2018, 213 n. 5 .

114 Cic. Rosc. Am.13 (praesidium); 27 (domus); 147 (ali, vestiri) with Dyck 2010, 77, 96-97, 201202.
} 
duty (antiquum officium) for helping Roscius herself (opitulata est), and praises her virtus, fides, and diligentia; ${ }^{15}$ in superlative language, he claims that she is a most spectacular woman (spectatissima femina) with illustrious (elite) male relatives, who, while being a woman, perfected virtue (virtute perfecit), such that as much honor (honor) was bestowed on her from their rank (dignitas), she returned no lesser ornaments (non minora ornamenta) from her renown (laus). ${ }^{116}$ High praise from Cicero. As Dixon, Skinner, and Kragelund have argued, her actions in safeguarding Roscius indicate her political authority and capacity in a time of political crisis. ${ }^{117}$ Not even Chrysogonus dared broach her doors. Her benefaction was intensely political, yet her political authority, perhaps emergent from her celebrated religious role with Iuno Sospita, as well as her ancestry and familial relations with Sulla, protected both her and Roscius. ${ }^{118}$ (Significantly, her second cousin, another Caecilia Metella, daughter of Lucius Caecilius Metellus Delmaticus, was Sulla's wife from 88 to 80 , whom he reputedly honored in all things. In 88 , after Sulla refused requests to restore the Marian fugitives, this Caecilia was called upon for aid. ${ }^{119}$ Both Caeciliae were politically influential women.) Cicero also received benefactions from women, including substantial amounts of money from his close friend Caerellia, a wealthy older woman; indebted to her, he even acted politically on her behalf, lobbying Publius Servilius Isauricus, propraetor in Asia in 46 , regarding her property there. ${ }^{120}$ For Cicero, female benefactions were an ever-present reality.

Livy offers a wealth of examples of female benefactions. Apart from the aforementioned matronal contributions for a donum for Delphic Apollo in 395, a ransom for the Gauls in 390, a donum for Iuno Regina in 217, and the dotal gold for the pelvis aurea for Iuno Regina in 207, Livy also records the matronal dedication of a bronze statue in the Temple of Iuno Regina in 218 and widows' contribution of their wealth (pecunia) to the aerarium in 214 during

\footnotetext{
115 Cic. Rosc. Am. 27 with Dyck 2010, 96-97.

116 Cic. Rosc. Am. 147 with Dyck 2010, 202.

117 Dixon 1983, 94-95; Skinner 2011, 48-49; Kragelund 2018, 214.

118 For Caecilia Metella's ancestry and familial relations, including her possible husband Appius Claudius Pulcher, consul in 79: Münzer 1920, 304 (stemma); Zmeskal 2009, 51, 74, 305. See further on the Metelli: Hölkeskamp 2017, 273-309. Cf. Osgood in this volume on the similarities between Caecilia Metella and Livia.

119 Plut. Sull. 6.12; App. B Civ. 1.63 with Keaveney 2005, 58; Kunst 2016, 204. Rohr Vio 2019, 145-146. For Caecilia Metella's ancestry and familial relations: Münzer 1920, 304 (stemma); Zmeskal 2009, 53-54.

120 Cic. Att.12.51.3; 15.26.4; Fam.13.72 (Publius Servilius Isauricus). See Austin 1946; Dixon 2001, 101.
} 
financial crisis. ${ }^{121}$ Livy's Valerius links the matronal contribution to the ransom of 390 with the widows' contribution of 214: he frames the earlier event as married women collecting for public use (in publicum conferre) and the later event as the widows' money (viduarum pecuniae) attending to the public treasury (audire aerarium) when money was needed (cum pecunia opus fuit). ${ }^{122}$ Nowhere does he denigrate these benefactions: instead, Livy frames them as necessary.

Female benefactions, then, were represented as shaping female privileges, as characteristically female, as capable of saving the res publica (from enemies and financial crisis) and individuals, and as frequent and necessary. By offering benefactions to people and deities, especially during times of need, female collectives and individuals bound themselves to the res publica.

\subsection{Family consilia}

In a recent contribution on Servilia's consilium, Flower has confirmed the "private but very political" nature of elite family consilia, meetings called to discuss "a course of action that needed to be decided upon."123 Their discussions and decisions had political consequences, as did those of the consilia of magistrates, and those of that "grand consilium in Rome," the Senate. ${ }^{124}$ Indeed, Flower has argued that senatorial, forensic, or contional orations may have "had their initial origins in remarks first prepared for a presentation in a consilium." ${ }^{125}$ As is abundantly clear in the case of Servilia, women could participate in, speak at, and influence politically consequential consilia. It was, after all, at such a consilium in June 44 that she promised to arrange for the removal of a grain commission from a senatorial decree. At the same consilium were present Servilia's daughter Tertia Iunia (Tertulla) and Porcia. ${ }^{126}$ Furthermore, in a letter to Brutus in July 43, Cicero indicates that Servilia organized and presided over another such a consilium wherein she sought his advice on whether to call Brutus home or not. ${ }^{127}$ Another salient example is Sempronia's consilium of 63 with the Catilinarian conspirators and the envoys of the Allobroges, which she hosted at her husband Decimus Iunius Brutus' home near the Forum while he was absent from Rome, although her role therein is uncertain. ${ }^{128}$ This was unquestionably

\footnotetext{
121 218: Livy 21.62.8. 214: Livy 24.18.13-14, 34.5.10.

122 Livy $34 \cdot 5 \cdot 9-10$.

123 Flower 2018, 253.

124 Flower 2018, 263.

125 Flower 2018, 264.

126 Cic. Att. 15.11.1 with Treggiari 2019, 190-191.

127 Cic. Ad Brut. 26.1 with Flower 2018, 259-26o; Treggiari 2019, 209.

128 Sall. Cat. 40.5 with Syme 1964, 69; Cadoux 1980, esp. 93; Ramsey 2007, 132, 169-170; Liu-
} 
a politically consequential meeting: the res publica was at stake! Servilia-and presumably other women like Sempronia-were part of the decision-making process in such consilia. Were these extraordinary events?

I propose that female participation in these informal, family consilia is clarified and illuminated by matronal meetings. If married women were (represented as being) able to hold politically significant meetings and issue communal decrees in the fourth and third centuries, then Servilia's authority and prominence in the consilia of 44 and 43 appears far less unusual. Elite married women had been meeting for centuries, feasibly as members of the ordo matronarum and for religious activity, and their collections and contributions attest to their organizational and decision-making skills. Moreover, their religious authority and vocabulary, gained from their religious roles, would have lent their words weight, as exemplified by Cornelia, Caecilia Metella, and the Vestal Fonteia. A woman of Servilia's experience and rank would have been a formidable presence at any meeting: is it any wonder Cicero restrained himself?

These examples of female intercession, benefactions, and family consilia testify to the breadth of possible practices of female interventions in politics. Women's pleas on behalf of others inside and outside of the domus were certainly political, but women also engaged in politically significant intercession through public and private reproach and dissuasion, offered politically significant public and private benefactions to people and deities, and presided over politically significant family consilia. The ordo matronarum, matronal meetings, and religious roles provided (some of the) foundations for these practices and none of these structures were represented as the novelty of the first century. We can see a little more of the iceberg.

bimova 2020, esp. 2. Sempronia's husband Decimus Iunius Brutus was consul in 77. Her ancestry is uncertain. Münzer proposed she was a daughter of Caius Sempronius Gracchus, Ciaceri a daughter of Caius Sempronius Tuditanus, consul in 129, and Syme a granddaughter of this same Tuditanus: Münzer 1920, 272-273; 1923, 1446; Ciaceri 1929/1930, 224-230; Syme 1964, 134-135. Cf. Cadoux 1980, 105-109; Ramsey 2007, 133; Zmeskal 2009, 243, 249; Liubimova 2020, 9-13. Most recently, Liubimova has proposed that Sempronia was a granddaughter of Caius Sempronius Gracchus: Liubimova 2020, 14-18, 22-23. I will not address the various prosopographical arguments here. However, I find Liubimova's proposal particularly attractive, given Sallust's favorable description of Sempronia's birth in Cat. 25.2 (genere ... satis fortunata fuit) — recalling Caius Sempronius Gracchus' own description of his high birth in C. Sempronius Gracchus fr. $47 \mathrm{ORF}^{4}$ (genere summo ortus essem - and Sempronia's probable age, viz. perhaps late thirties to mid-forties following Cat. 24.3, 25.2: Ramsey 2007, 133 (age); Cadoux 1980, 95-96, 106 (age); Liubimova 2020, 11, 16-17 (age, high birth). 
Women were excluded from some structures and practices of politics in the libera res publica. There were no female consuls or pontifices maximi. But that did not preclude them from engaging in the res publica. To return to Münzer: "für die ganze Einmischung der Frauen in die Kämpfe der Parteien, für jene Hauspolitik der adligen Damen, die mit echt weiblichen Mitteln arbeitete, aber vor den höchsten Zielen männlichen Ehrgeizes nicht zurückschrak, bieten den besten Beweis die Frauen aus dem Servilischen Geschlecht, zumal die ältere Halbschwester Catos." ${ }^{129}$ While distancing myself from Münzer's "echt weiblichen Mitteln" (purely womanly means), I acknowledge that female political interventions frequently occurred in domestic contexts, as exemplified by Servilia's consilia. But we need to cross the limen of the domus and look to the ordo, coetus (meetings), and aedes (religious roles) for other, equally formidable interventions. These were represented as effective, legitimate, and occasionally laudable structures for female engagement in the res publica. The formality and apparent antiquity of these structures authorized and legitimized collective and individual actions by elite women and priestesses. None of these structures were represented as novel. Of note are the public honors bestowed on married women and the members of the ordo for their benefactions, the communal decree of the matronal coetus, and the religious authority and capacity of priestesses and elite women. We must never forget that the safety of the res publica was thought to be dependent on the prayers of women.

Nor did political interventions primarily take the form of "die Bitte." Elite women could also intervene through the reproach and dissuasion of powerful men, through benefactions that saved individuals, collectives, and the res publica, and through significant roles in elite family consilia.

The chaos of civil war certainly produced new possibilities for elite women and politics: Fulvia is a prime example. But she was not operating in a vacuum: many elite women preceded her. Indeed, she explicitly rejected their pre-existing structures and practices when she rebuffed Hortensia and the ordo in 42. We have Fulvia to thank for Hortensia's oration, which itself reveals the proactive engagement of women in the res publica despite Hortensia's reputed claims to the contrary.

129 "For the complete involvement of women in the struggles of the parties, for the domestic politics of aristocratic ladies, who worked with purely womanly means, but did not shrink from the highest aims of manly ambition, the best evidence is offered by women of the Servilian clan, especially Cato's elder half-sister" (Münzer 1920, 426-427). 
Finally, I return to Livy's Valerius and his response to Cato's outrage at women engaging in the res publica. Addressing Cato, he demands to know what is novel about the female lobby against the lex Oppia in 195:

For what so novel thing have married women done by appearing in public as a crowd concerning a matter pertaining to them? Have they never appeared in public before? I will unroll your own Origines against you. Hear how often they have done it, and, in fact, always for the public good!130

Valerius then recounts the intercession of the Sabines, the intercession of women with Coriolanus, the benefactions of married women that saved Rome from the Gauls in 390, the widows' benefactions to the aerarium in 214, and finally the matronal inaugural procession for Magna Mater in $204 .{ }^{131} \mathrm{He}$ defends the female lobby of 195 on the basis that "it is satisfactory to vindicate them if nothing novel has been done."132 His subsequent claim presages my own findings: "nobody was surprised at action they took in matters concerning everyone, men and women alike."133

Female engagement in the res publica was neither the novelty of the first century вСЕ nor exceptional, for the interventions of women like Servilia or Terentia were manifestations of a long tradition of women seizing political initiative. Rem publicam capessere was more than possible for women in the libera res publica: it was customary.

\section{Bibliography}

Austin, L. (1946) “The Caerellia of Cicero's Correspondence”, Classical Journal 41, 305309 .

Babcock, C. (1965) "The Early Career of Fulvia", American Journal of Philology 86, 1-32. Balsdon, J. (1962) Roman Women: Their History and Habits, London.

Bauman, R. (1992) Women and Politics in Ancient Rome, London.

130 Livy 34.5.7: nam quid tandem novi matronae fecerunt, quod frequentes in causa ad se pertinente in publicum processerunt? nunquam ante hoc tempus in publico apparuerunt? tuas adversus te Origines revoluam. accipe quotiens id fecerint, et quidem semper bono publico.

131 Livy 34.5.8-10.

132 Livy 34.5.11: nihil novi factum purgare satis est.

133 Livy 34.5.12: ceterum quod in rebus ad omnes pariter viros feminas pertinentibus fecisse eas nemo miratus est. 
Beness, L. \& Hillard, T. (2013) "Insulting Cornelia, Mother of the Gracchi”, Antichthon $47,61-79$.

Berg, R. (2002) "Wearing Wealth. Mundus muliebris and Ornatus as Status Markers for Women in Imperial Rome", in R. Berg et al. (eds.), Women, Wealth and Power in the Roman Empire (Rome): 15-73.

Bispham, E. (2006) "Literary Sources", in N. Rosenstein \& R. Morstein-Marx (eds.), A Companion to the Roman Republic (Malden, MA \& Oxford): 29-50.

Böels-Janssen, N. (1993) La vie religieuse des matrones dans la Rome archä̈que, Rome.

Böels-Janssen, N. (2008) "Maiestas Matronarum”, Latomus 67, 37-55.

Borrello, S. (2014) "Prudentissima et diligentissima femina Servilia, M. Bruti mater, tra Cesariani e Cesaricidi", in F. Cenerini \& F. Rohr Vio (eds.), Matronae in domo et in re publica agentes. Spazi e occasioni dell'azione femminile nel mondo romano tra tarda repubblica e primo impero (Trieste): 165-191.

Boyce, A. (1937) "The Expiatory Rites of 207 B.c.", Transactions and Proceedings of the American Philological Association 68, 157-171.

Braddick, M. (2005) "State Formation and Political Culture in Elizabethan and Stuart England”, in R. Asch \& D. Freist (eds.), Staatsbildung als kultureller Prozess. Strukturwandel und Legitimation von Herrschaft in der Frühen Neuzeit (Köln): 69-9o.

Brennan, T.C. (2012) “Perceptions of Women's Power in the Late Republic: Terentia, Fulvia, and the Generation of 63 вСЕ", in S.L. James \& S. Dillon (eds.), A Companion to Women in the Ancient World (Malden, MA \& Oxford): 354-366.

Briscoe, J. (1981) A Commentary on Livy, Books XXXIV-XXXVII, Oxford.

Broughton, T.R.S. (1951) The Magistrates of the Roman Republic, Vol. 1, New York.

Broughton, T.R.S. (1952) The Magistrates of the Roman Republic, Vol. 2, New York.

Brown, R. (1995) "Livy's Sabine Women and the Ideal of Concordia", Transactions and Proceedings of the American Philological Association 125, 291-319.

Buonopane, A. (2016) "Terenzia, una matrona in domo et in re publica agens", in F. Cenerini \& F. Rohr Vio (eds.), Matronae in domo et in re publica agentes. Spazi e occasioni dell'azione femminile nel mondo romano tra tarda repubblica e primo impero (Trieste): $5^{1-64}$.

Cadoux, T. (1980) "Sallust and Sempronia", in B. Marshall (ed.), Vindex Humanitatis: Essays in Honour of John Huntly Bishop (Armidale): 93-122.

Cantarella, E. (2016) "Women and Patriarchy in Roman Law", in C. Ando, P. du Plessis \& K. Tuori (eds.), The Oxford Handbook of Roman Law and Society (Oxford): 419-431.

Cenerini, F. \& Rohr Vio, F. (eds.) (2016) Matronae in domo et in re publica agentes. Spazi e occasioni dell'azione femminile nel mondo romano tra tarda repubblica e primo impero, Trieste.

Champlin, E. (1991) Final Judgments: Duty and Emotion in Roman Wills, 200B.C.A.D.250, Berkeley.

Christ, K. (1993) “Die Frauen der Triumvirn”, in A. Gara \& D. Foraboschi (eds.), Il Triumvi- 
rato costituente alla fine della Repubblica: scritti in onore di Mario Attilio Levi(Como): $135^{-153 .}$

Christenson, D. (2000) Plautus. Amphitruo, Cambridge.

Ciaceri, E. (1929/1930) "La dama Sempronia nella congiura di Catilina", Atti della Reale Accademia di archeologia, lettere e belle arti 11, 217-230.

Cluett, R. (1998) "Roman Women and Triumviral Politics, 43-37 B.C.", Echos du Monde Classique/Classical Views 42 n.s. 17, 67-84.

Cornell, T.J. et al. (eds.) (2013) The Fragments of the Roman Historians, Vol. 3. Commentary, Oxford.

Courtney, E. (1999) Archaic Latin Prose, Atlanta.

Culham, P. (2004) "Women in the Roman Republic", in H.I. Flower (ed.), The Cambridge Companion to the Roman Republic (Cambridge): 139-159.

Dettenhoffer, M. (1994) "Frauen in politischen Krisen: Zwischen Republik und Prinzipat”, in M. Dettenhofer (ed.), Reine Männersache? Frauen in Männerdomänen der antiken Welt (Köln): 133-157.

DiLuzio, M. (2016) A Place At the Altar. Priestesses in Republican Rome, Princeton.

Dixon, S. (1983) "A Family Business: Women's Role in Patronage and Politics at Rome 80-44 BC", Classica et Mediaevalia 34, 91-112.

Dixon, S. (1988) The Roman Mother, London.

Dixon, S. (2001) Reading Roman Women: Sources, Genres and Real Life, London.

Dixon, S. (2004) "Exemplary Housewife or Luxurious Slut? Cultural Representations of Women in the Roman Economy", in F. McHardy \& E. Marshall (eds.), Women's Influence on Classical Civilization (London): $56-74$.

Dixon, S. (2007) Cornelia. Mother of the Gracchi, London.

Dyck, A. (2010) Cicero. Pro Sexto Roscio, Cambridge.

Elster, M. (2003) Die Gesetze der mittleren römischen Republik, Darmstadt.

Epstein, D. (1987) Personal Enmity in Roman Politics 218-43 BC, London.

Evans, J. (1991) War, Women, and Children in Ancient Rome, London.

Fantham, E. (2004) "Literature in the Roman Republic", in H.I. Flower (ed.), The Cambridge Companion to the Roman Republic (Cambridge): 271-293.

Fantham, E. (2011) Roman Readings: Roman Response to Greek Literature from Plautus to Statius and Quintilian, Berlin.

Flach, D. (1994) Die Gesetze der frühen römischen Republik: Text und Kommentar, Darmstadt.

Flower, H.I. (1998) “Rethinking 'Damnatio Memoriae': The Case of Cn. Calpurnius Piso Pater in AD 20", Classical Antiquity 17, 155-187.

Flower, H.I. (2002) “Were Women Ever 'Ancestors' in Republican Rome?", in J. Munk Højte (ed.), Images of Ancestors (Aarhus): 157-182.

Flower, H.I. (2015) “Sulla's Memoirs as an Account of Individual Religious Experience", Religion in the Roman Empire 1, 297-320. 
Flower, H.I. (2018) "Servilia's consilium: Rhetoric and Politics in a Family Setting", in H. van der Blom, C. Gray \& C. Steel (eds.), Institutions and Ideology in Republican Rome: Speech, Audience and Decision (Cambridge): 252-264.

Foubert, L. (2016) "Crowded and Emptied Houses as Status Markers of Aristocratic Women in Rome. The Literary Commonplace of the domus frequentata", EuGeStA $6,129-15$ o.

Froese, M. (2004) "Berühmt und berüchtigt—politisch aktive Römerinnen im 1. Jh. v. Chr.", in B. Miemietz (ed.), Blickpunkt: Frauen- und Geschlechterstudien (St. Ingbert): 205-213.

Gallia, A. (2015) “Vestal Virgins and Their Families”, Classical Antiquity 34, 74-120.

Geertz, C. (1973) The Interpretation of Cultures, New York.

Glinister, F. (1997) "Women and Power in Archaic Rome”, in T.J. Cornell \& K. Lomas (eds.), Gender and Ethnicity in Ancient Italy (London): 115-127.

Günther, R. (2000) "Sexuelle Diffamierung und politische Intrigen in der Republik: P. Clodius Pulcher und Clodia", in T. Späth \& B. Wagner-Hasel (eds.), Frauenwelten in der Antike: Geschlechterordnung und weibliche Lebenspraxis (Stuttgart): 227241.

Gruen, E. (1990) Studies in Greek Culture and Roman Policy, Berkeley.

Hall, J. (2014) Cicero's Use of Judicial Theater, Ann Arbor.

Hallett, J. (1984) Fathers and Daughters in Roman Society. Women and the Elite Family, Princeton.

Hallett, J. (2002) "Women Writing in Rome and Cornelia Mother of the Gracchi", in L. Churchill, P. Brown \& J. Jeffrey (eds.), Women Writing Latin: Women Writing Latin in Roman Antiquity, Late Antiquity, and the Early Christian Era (London): 13-24.

Hallett, J. (2010) "Human Connections and Paternal Evocations: Two Elite Roman Women Writers and the Valuing of Others", in R. Rosen \& I. Sluiter (eds.), Valuing Others in Classical Antiquity (Leiden \& Boston), 353-373.

Hallett, J. (2018) "Oratorum Romanarum Fragmenta Liberae Rei Publicae: The Letter of Cornelia, Mater Gracchorum, and the Speeches of her Father and Son", in C. Gray et al. (eds.), Reading Republican Oratory. Reconstructions, Contexts, Receptions (Oxford): 309-318.

Hänninen, M.-L. (1999a) "The Dream of Caecilia Metella: Aspects of Inspiration and Authority in Late Republican Roman Religion", in P. Setälä \& L. Savunen (eds.), Female Networks and the Public Sphere in Roman Society (Rome): 29-38.

Hänninen, M.-L. (1999b) “Juno Regina and Roman Matrons”, in P. Setälä \& L. Savunen (eds.), Female Networks and the Public Sphere in Roman Society (Rome): $39^{-52}$.

Harders, A.-C. (2008) Suavissima Soror. Untersuchungen zu den Bruder-SchwesterBeziehungen in der römischen Republik, München.

Harders, A.-C. (2014) “'Kann man(n) Frauen vertrauen?': Zur Rolle und Bedeutung von Frauen in aristokratischen Nahbeziehungen während der römischen Republik”, in 
S. Feickert \& A. Haut (eds.), Faces of Communities: Social Ties between Trust, Loyalty and Conflict (Göttingen): 77-96.

Hemelrijk, E. (1987) “Women's Demonstrations in Republican Rome”, in J. Blok \& P. Mason (eds.), Sexual Asymmetry. Studies in Ancient Society (Amsterdam): 217-240.

Hemelrijk, E. (1999) Matrona Docta. Educated Women in the Roman Élite from Cornelia to Julia Domna, London.

Hillard, T. (1983) "Materna Auctoritas. The Political Influence of Roman Matronae", Classicum 22, 10-13.

Hillard, T. (1989) "Republican Politics, Women, and the Evidence", Helios 16, 165-182.

Hillard, T. (1992) "On the Stage, Behind the Curtain: Images of Politically Active Women in the Late Roman Republic", in B. Garlick, S. Dixon \& P. Allen (eds.), Stereotypes of Women in Power: Historical Perspectives and Revisionist Views (Westport): 37-64.

Hillard, T. (2001) "Popilia and laudationes funebres for Women", Antichthon 35, 45-63 [with "Erratum: vol. 35 (2001)", Antichthon 36 (2002), 80].

Hillard, T. (2014) "Prosopographia shared by Pliny and Solinus: The question of Solinus' Source(s)", in K. Brodersen (ed.), Solinus. New Studies (Heidelberg), 43-74.

Hin, S. (2008) "Counting Romans", in L. de Ligt \& S. Northwood (eds.), People, Land, and Politics: Demographic Developments and the Transformation of Roman Italy, 300 BCAD 14 (Leiden \& Boston): 187-238.

Hölkeskamp, K.-J. (2010) Reconstructing the Roman Republic: An Ancient Political Culture and Modern Research, Princeton.

Hölkeskamp, K.-J. (2017) Libera res publica. Die politische Kultur des antiken RomPositionen und Perspektiven, Stuttgart.

Hopwood, B. (2015) “Hortensia Speaks. An Authentic Voice of Resistance?”, in K. Welch (ed.), Appian's Roman History. Empire and Civil War (London): 305-322.

Hudson, J. (2016) “Carpento certe: Conveying Gender in Roman Transportation”, Classical Antiquity 35, 215-246.

Johnson, M. (2007) The Pontifical Law of the Roman Republic. Diss. Rutgers University. Keaveney, A. (2005) Sulla. The Last Republican, 2nd ed., London.

Köves, T. (1963) “Zum Empfang der Magna Mater in Rom”, Historia 12, 321-347.

Kragelund, P. (2018) "Epicurus, Sisenna, and the Dream of Metella", Classical Philology $113,212-224$.

Kunst, C. (2016) "Formen der Intervention einflussreicher Frauen", in A. Bielman Sánchez, I. Cogitore \& A. Kolb (eds.), Femmes influentes dans le monde hellénistique et à Rome (Grenoble): 197-216.

Laurence, R. (1997) "History and Female Power at Rome", in T.J. Cornell \& K. Lomas (eds.), Gender and Ethnicity in Ancient Italy (London): 129-139.

Lejeune, F. (2012) “Les interventions des femmes de l' entourage des imperatores dans la sphere publique de la mort de César aux accords de Misène”, in R. Baudry \& S. Destephen (eds.), La société romaine et ses élites (Paris): 99-107. 
Liubimova, O. (2020) "The Mother of Decimus Brutus and the Wife of Gaius Gracchus", Mnemosyne (Advance Articles), 1-26. DOI: https://doi.org/10.1163/1568525X -BJA10005

Lucchelli, M. \& Rohr Vio, F. (2016) "La ricchezza delle matrone: Ortensia nella dialettica politica al tramonto della repubblica”, in A. Bielman Sánchez, I. Cogitore \& A. Kolb (eds.), Femmes influentes dans le monde hellénistique et à Rome (Grenoble): $175^{-196 .}$

MacLean, R. (2018) Freed Slaves and Roman Imperial Culture, Cambridge.

Manzo, B. (2016) "La parola alle matrone. Interventi femminili in sedi pubbliche nell' età tardo repubblicana", in F. Cenerini \& F. Rohr Vio (eds.), Matronae in domo et in re publica agentes. Spazi e occasioni dell'azione femminile nel mondo romano tra tarda repubblica e primo impero (Trieste): 121-136.

Meier, C. (1966) Res publica amissa: Eine Studie zu Verfassung und Geschichte der Späten Römischen Republik, Wiesbaden.

Milnor, K. (2005) Gender, Domesticity, and the Age of Augustus: Inventing Private Life, Oxford.

Milnor, K. (2009) "Women in Roman Historiography”, in A. Feldherr (ed.), The Cambridge Companion to the Roman Historians (Cambridge): 276-287.

Münzer, F. (1920) Römische Adelsparteien und Adelsfamilien, Stuttgart.

Münzer, F. (1923) “103) Sempronia”, in RE, Zweite Reihe, Vierter Halbband (Stuttgart), 1446.

Münzer, F. (1931) "82) Ser. Sulpicius Paterculus", in RE, Zweite Reihe, Siebter Halbband (Stuttgart), 817 .

Nathan, G. (2003) "Pudicitia Plebeia: Womanly Echoes in the Struggle of the Orders", in C. Deroux (ed.), Studies in Latin Literature and Roman History, Vol. 11 (Brussels): $53-64$.

Northwood, S. (2008) "Census and Tributum”, in L. de Ligt \& S. Northwood (eds.), People, Land, and Politics: Demographic Developments and the Transformation of Roman Italy, 300 BC-AD 14 (Leiden \& Boston): 257-270.

Oakley, S. (2005) A Commentary on Livy, Books VI-X, Vol. Iv: Book X, Oxford.

Ogilvie, R. (1965) A Commentary on Livy. Books 1-5, Oxford.

Osgood, J. (2014) Turia: A Roman Woman's Civil war, Oxford.

Östenberg, I. (forthcoming) "Gendering the Elite Roman Funeral", in H. Cornwell \& G. Woolf (eds.), Gendering Roman Imperialism (Cambridge).

Palmer, R. (1974) "Roman Shrines of Female Chastity from the Caste Struggle to the Papacy of Innocent I”, Rivista Storica dell'Antichità 4, 113-159.

Palmer, R. (1997) Rome and Carthage at Peace, Stuttgart.

Pölönen, J. (1999) "Lex Voconia and Conflicting Ideologies of Succession. Privileging Agnatic Obligation over Cognatic Family Feeling", Arctos 33, 111-131.

Pomeroy, S. (1975) Goddesses, Whores, Wives \& Slaves, New York. 
Purcell, N. (1986) "Livia and the Womanhood of Rome", Proceedings of the Cambridge Philological Society 32, 78-105.

Ramsey, J. (2007) Sallust's Bellum Catilinae, 2nd ed., Oxford.

Richlin, A. (2014), Arguments with Silence: Writing the History of Roman Women, Ann Arbor.

Ridley, R. (200o) “The Dictator's Mistake: Caesar's Escape from Sulla”, Historia 49, 211229.

Rohr Vio, F. (2013) Fulvia. Una Matrona tra i 'signori della guerra', Napoli.

Rohr Vio, F. (2014) "La voce e il silenzio: il dissenso delle matrone al tramonto della Repubblica", in R. Cristofoli, A. Galimberti \& F. Rohr Vio (eds.), Lo spazio del nonallineamento a Roma fra tarda Repubblica e primo principato forme e figure dell'opposizione politica (Roma): 95-115.

RohrVio, F. (2015) "Dux femina: Fulvia in armi nella polemica politica di età triumvirale", in T. Lucchelli \& F. Rohr Vio (eds.), Virimilitares. Rappresentazione e propaganda tra Repubblica e Principato (Trieste): 61-89.

Rohr Vio, F. (2016) "Prestigio 'al femminile' tra novitas e mos maiorum", in R. Baudry \& F. Hurlet (eds.), Le Prestige à Rome à la fin de la République et au début du Principat (Paris): 105-115.

Rohr Vio, F. (2017) "Protagoniste della memoria, interpreti del passato, artefici del futuro: matronae doctae nella tarda repubblica", in C. Roberto, A. Galimberti \& F. Rohr Vio (eds.), Costruire la memoria: uso e abuso della storia fra tarda Repubblica e primo Principato: Venezia, 14-15 gennaio 2016 (Roma): 95-112.

Rohr Vio, F. (2019) Le custodi del potere. Donne e politica alla fine della repubblica Romana, Roma.

Rohr Vio, F. (forthcoming) "Matronae and Politics in Republican Rome", in V. Arena \& J. Prag (eds.), A Companion to the "Political Culture" of the Roman Republic (London). Roller, M. (2018) Models from the Past in Roman Culture:A World of Exempla, Cambridge. Rosillo-López, C. (2017) Public Opinion and Politics in the Late Roman Republic, Cambridge.

Rotondi, G. (1912) Leges publicae populi Romani, Milano.

Ryan, F. (1998) Rank and Participation in the Republican Senate, Stuttgart.

Saller, R. (1994) Patriarchy, Property and Death in the Roman Family, Cambridge.

Schultz, C. (2006a) "Juno Sospita and Roman Insecurity in the Social War", in C. Schultz \& P. Harvey (eds.), Religion in Republican Italy (Cambridge): 207-227.

Schultz, C. (2006b) Women's Religious Activity in the Roman Republic, Chapel Hill.

Skinner, M. (2011) Clodia Metelli: The Tribune's Sister, Oxford.

Stockert, W. (2012) T. Maccius Plautus. Cistellaria: Einleitung, Text und Kommentar, München.

Sumi, G. (2004) "Civil War, Women and Spectacle in the Triumviral Period", Ancient World 35, 196-2o6. 
Syme, R. (1939) The Roman Revolution, Oxford.

Syme, R. (1964) Sallust, Berkeley.

Syme, R. (1986) The Augustan Aristocracy, Oxford.

Tatum, J. (1990) “Cicero and the Bona Dea Scandal”, Classical Philology 85, 202-208.

Treggiari, S. (1969) Roman Freedmen during the Late Republic, Oxford.

Treggiari, S. (2002) Roman Marriage. Iusti coniuges from the Time of Cicero to the Time of Ulpian, Oxford.

Treggiari, S. (2007) Terentia, Tullia and Publilia: The Women of Cicero's Family, London.

Treggiari, S. (2019) Servilia and her Family, Oxford.

Valentini, A. (2012) Matronae tra novitas e mos maiorum: spazi e modalità dell'azione pubblica femminile nella Roma medio repubblicana, Venice.

Valentini, A. (2014) "Ottavia la prima 'First Lady of Imperial Rome', in F. Cenerini \& F. Rohr Vio (eds.), Matronae in domo et in re publica agentes. Spazi e occasioni dell'azione femminile nel mondo romano tra tarda repubblica e primo impero (Trieste): $239-255$.

Walbank, F. (1967) A Historical Commentary on Polybius, Vol. 2. Commentary on Books VII-XVIII, Oxford.

Walbank, F. (1979) A Historical Commentary on Polybius, Vol. 3. Commentary on Books XIX-XL, Oxford.

Walbank, F. (1985) Selected Papers. Studies in Greek and Roman History and Historiography, Cambridge.

Webb, L. \& Brännstedt, L. (forthcoming) "Gendering the Roman Triumph: Elite Women and the Triumph in the Republic and Early Empire”, in H. Cornwell \& G. Woolf (eds.), Gendering Roman Imperialism (Cambridge).

Webb, L. (2017) "Gendering the Roman imago", EuGeStA 7, 140-183.

Webb, L. (2018) "Religious Leadership-Ancient Roman Religions”, in S. de Gaia (ed.), Encyclopedia of Women in World Religions: Faith and Culture Across History (Santa Barbara): 68-71.

Webb, L. (2019) "Mihi es aemula: Elite Female Status Competition in Mid-Republican Rome and the Example of Tertia Aemilia", in C. Damon \& C. Pieper (eds.), Eris vs. Aemulatio. Valuing Competition in Classical Antiquity (Leiden \& Boston): 251280.

Webb, L. (forthcoming) "Exaequatio and aemulatio: Regulation of Elite Female Status Competition in Mid-Republican Rome", in M. Bayless, J. Liliequist \& L. Webb (eds.), Gender and Status Competition in Pre-Modern Societies (Turnhout).

Weissenborn, W. (1863) Titi Livi Ab Urbe Condita Libri, Bd. 6. Buch XXVII-XXX, Berlin. Weissenborn, W. (1865) Titi Livi Ab Urbe Condita Libri, Bd. 2. Buch III-V, Berlin.

Weissenborn, W. (1872) Titi Livi Ab Urbe Condita Libri, Bd. 4. Buch XXI-XXIII, Berlin. Welch, K. (1995) “Antony, Fulvia, and the Ghost of Clodius in 47 B.C.", Greece \& Rome 42, 182-201. 
Welch, K. (2012) Magnus Pius: Sextus Pompeius and the Transformation of the Roman Republic, Swansea.

Welch, K. (forthcoming) "Memorable Women and Women in the Memory of Civil War".

Zmeskal, K. (2009) Adfinitas. Die Verwandtschaften der senatorischen Führungsschicht der römischen Republikvon 218-31 v. Chr., Passau. 